\title{
Phase evolution in reaction sintered zirconium titanate based materials
}

\author{
E. López-López ${ }^{1}$, M.L. Sanjuán ${ }^{2}$, R. Moreno ${ }^{1}$ and C. Baudín ${ }^{* 1}$ \\ ${ }^{1}$ Instituto de Cerámica y Vidrio (CSIC), C/ Kelsen 5, 28049, Madrid, España \\ ${ }^{2}$ Instituto de Ciencia de Materiales de Aragón (CSIC), Facultad de Ciencias \\ Universidad de Zaragoza, 50009 Zaragoza, España
}

\begin{abstract}
Zirconium titanate materials are proposed for structural components for which fully reacted and relatively large pieces are required. In this work the phase evolution in slip cast compacts constituted by equimolar mixtures of $\mathrm{TiO}_{2}$ and $\mathrm{ZrO}_{2}$ stabilized with 3 mol\% of $\mathrm{Y}_{2} \mathrm{O}_{3}$ at high temperature is studied, to establish the basis to design suitable thermal treatments for $\mathrm{ZrO}_{2}\left(\mathrm{Y}_{2} \mathrm{O}_{3}\right)-\mathrm{TiO}_{2}$ materials. The temperatures at which the processes involved in the reaction sintering occurred were identified by constant heating rate experiments. Phase and microstructure analyses have been performed on specimens treated at the identified temperatures and air quenched. Then the adequate temperature range to get fully reacted and dense materials has been deduced. Materials treated at $1500^{\circ} \mathrm{C}-2 \mathrm{~h}$ were constituted by $\mathrm{Zr}_{5} \mathrm{Ti}_{7} \mathrm{O}_{24}$ as major phase, a solid solution of $\mathrm{TiO}_{2}$ and $\mathrm{Y}_{2} \mathrm{O}_{3}$ in c- $\mathrm{ZrO}_{2}$ as secondary phase and a $\mathrm{ZrO}_{2}-\mathrm{TiO}_{2}-\mathrm{Y}_{2} \mathrm{O}_{3}$ non-stoichiometric compound with pyrochlore structure as minor phase. Pyrochlore was demonstrated to be a metastable phase at $1500^{\circ} \mathrm{C}$.
\end{abstract}

Key words: A. Sintering, B. Microstructure-final, D. $\mathrm{ZrO}_{2}, \mathrm{TiO}_{2}$, Zirconium titanate.

\footnotetext{
"Corresponding author. Tel.: +34 917355840; fax: +34 917355843. E-mail address: cbaudin@icv.csic.es
} 


\section{Introduction}

The stoichiometric zirconium titanate, $\mathrm{ZrTiO}_{4}$, presents crystallographic anisotropy in thermal expansion $\left(\alpha_{\mathrm{a} 25-800^{\circ} \mathrm{C}}=6.2 \times 10^{-6{ }^{\circ}} \mathrm{C}^{-1}, \alpha_{\mathrm{b} 25-800^{\circ} \mathrm{C}}=10 \times 10^{-6{ }^{\circ}} \mathrm{C}^{-1}, \alpha_{\mathrm{c} 25-}\right.$

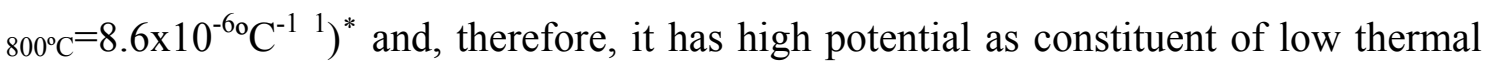
expansion materials for structural applications. Thus, the fabrication of relatively large bulk pieces would be required. A main problem of the materials whose low thermal expansion derives from anisotropy is that it is usually associated to extensive microcracking. In this sense, it would be desirable to count with a phase compatible with zirconium titanate such as a zirconia polymorph, to add as reinforcing second phase for which the possibility of obtaining materials in the $\mathrm{ZrO}_{2}-\mathrm{TiO}_{2}-\mathrm{Y}_{2} \mathrm{O}_{3}$ system would be adequate. As discussed below, the composition and structure of zirconium titanate are variable as a function of the experimental parameters used to obtain the material. Moreover, there is no general agreement on the phase equilibrium relationships in the $\mathrm{ZrO}_{2}-\mathrm{TiO}_{2}-\mathrm{Y}_{2} \mathrm{O}_{3}$ system. Therefore, the study of the phase development in zirconium titanate based materials is required.

The formation of $\mathrm{ZrTiO}_{4}$ has been studied by several authors ${ }^{2-10}$. Although it is possible to obtain $\mathrm{ZrTiO}_{4}$ at temperatures around $600^{\circ} \mathrm{C}$ by sol gel methods ${ }^{2}$, the solid state reaction from the oxides of zirconium and titanium is required for the fabrication of relatively large bulk pieces. According to calculations by Hom et al. ${ }^{3}$ the formation of $\mathrm{ZrTiO}_{4}$ from the oxides is thermodynamically favourable from about $980^{\circ} \mathrm{C}(1250 \pm 150$ $\mathrm{K})$, however, it has only been reported at temperatures between $1300^{\circ} \mathrm{C}$ and $1600^{\circ} \mathrm{C}^{3-10}$. The stoichiometric zirconium titanate $\left(\mathrm{ZrTiO}_{4}\right)$ is the stable phase at high temperature $\left(>1200^{\circ} \mathrm{C}^{9}\right)$, whereas, for lower temperatures $\left(<1100^{\circ} \mathrm{C}\right)$ the composition of zirconium titanate shifts towards higher $\mathrm{TiO}_{2}$ contents. McHale and Roth ${ }^{9}$, after annealing

\footnotetext{
* Lattice: Orthorhombic. Space group: Pnab. $a=5.03580 \mathrm{~nm}, \mathrm{~b}=5.48740 \mathrm{~nm}, \mathrm{c}=4.80180 \mathrm{~nm}$. ASTM $34-415$
} 
compacts with the stoichiometric composition $\left(\mathrm{ZrTiO}_{4}\right)$ at $1000^{\circ} \mathrm{C}$ for more than 4 months, concluded that the composition of the stable phase of zirconium titanate below $1100^{\circ} \mathrm{C}$ was $\mathrm{ZrTi}_{2} \mathrm{O}_{6}$. For lower annealing periods the obtained phase was $\mathrm{Zr}_{5} \mathrm{Ti}_{7} \mathrm{O}_{24}{ }^{9,11}$. For relatively short thermal treatments such as those used in ceramic processing, $\mathrm{Zr}_{5} \mathrm{Ti}_{7} \mathrm{O}_{24}$ is only formed in the presence of additives such as $\mathrm{Y}_{2} \mathrm{O}_{3}{ }^{12,13}$.

Even though the complete $\mathrm{ZrO}_{2}-\mathrm{TiO}_{2}-\mathrm{Y}_{2} \mathrm{O}_{3}$ phase equilibrium diagram has not been established, there are some studies of the isothermal sections at $1500^{\circ} \mathrm{C}^{14-17}$. All authors agree that for equimolar mixtures of $\mathrm{TiO}_{2}$ and $\mathrm{ZrO}_{2}$ and low $\mathrm{Y}_{2} \mathrm{O}_{3}$ contents $(<1$ mol\%) the only stable phase would be zirconium titanate solid solution while for higher $\mathrm{Y}_{2} \mathrm{O}_{3}$ contents these studies predict different phases. Colomer ${ }^{14}$ predicts a solid solubility limit of $\mathrm{Y}_{2} \mathrm{O}_{3}$ in zirconium titanate at $1500^{\circ} \mathrm{C}$ about $3 \mathrm{~mol} \%$, being the compatible phases for higher $\mathrm{Y}_{2} \mathrm{O}_{3}$ amounts zirconium titanate and cubic zirconia. Schaedler ${ }^{16}$ and Kobayashi ${ }^{17}$ also predict these phases for compositions out of the region of $\mathrm{Y}_{2} \mathrm{O}_{3}$ solid solution in zirconium titanate but setting the limits of solubility of $\mathrm{Y}_{2} \mathrm{O}_{3}$ in zirconium titanate in $\approx 1 \mathrm{~mol} \%$ and $\approx 0.5 \mathrm{~mol} \%$, respectively. The compatible phases proposed by Feighery ${ }^{15}$ out of the region of $\mathrm{Y}_{2} \mathrm{O}_{3}$ solid solution in zirconium titanate are pyrochlore and zirconium titanate, with a limit of solubility of $\mathrm{Y}_{2} \mathrm{O}_{3}$ in zirconium titanate of $\approx 1 \mathrm{~mol} \%$. According to Schaedler et al. ${ }^{16}$, the compatibility between zirconium titanate and pyrochlore is only possible at lower temperature $\left(1300^{\circ} \mathrm{C}\right)$

However, there are no experimental data in the above mentioned studies that allow establishing the exact point for the solid solubility limit of $\mathrm{Y}_{2} \mathrm{O}_{3}$ in zirconium titanate at $1500^{\circ} \mathrm{C}$. Colomer et al. ${ }^{14}$ focused the studies in the zirconia-rich region $(65-$ $97 \mathrm{~mol} \%$ ), the closest composition studied by Schaedler et al. ${ }^{16}$ was $42.1 \mathrm{~mol} \% \mathrm{ZrO}_{2}$, $52.6 \mathrm{~mol} \% \mathrm{TiO}_{2}, 5.3 \% \mathrm{~mol} \mathrm{Y}_{2} \mathrm{O}_{3}$, and the only compositions in the zirconium titanate 
primary field analysed by Feighery et al. ${ }^{15}$ and Kobayashi et al. ${ }^{17}$ where in the $\mathrm{ZrO}_{2}$ $\mathrm{TiO}_{2}$ binary system. The closest compositions studied by these authors are $\approx 54.5 \mathrm{~mol} \%$ $\mathrm{ZrO}_{2}, \approx 44.0 \mathrm{~mol} \% \mathrm{TiO}_{2}, \approx 1.5 \mathrm{~mol}^{2} \mathrm{Y}_{2} \mathrm{O}_{3}{ }^{15}$ and $\approx 48.0 \mathrm{~mol} \% \mathrm{ZrO}_{2}, \approx 48.0 \mathrm{~mol} \% \mathrm{TiO}_{2}$, $\approx 4.0 \mathrm{~mol} \% \mathrm{Y}_{2} \mathrm{O}_{3}{ }^{17}$. McHale and Roth ${ }^{9}$ studied compositions with $0.5 \mathrm{~mol} \%$ of $\mathrm{Y}_{2} \mathrm{O}_{3}$ and different contents of $\mathrm{ZrO}_{2}(41.46-54.73 \mathrm{~mol} \%)$ and $\mathrm{TiO}_{2}(58.04-44.77 \mathrm{~mol} \%)$ at $1500^{\circ} \mathrm{C}$ for which zirconium titanate was the only phase.

Furthermore, Fagg et al. ${ }^{18}$ studied the solubility limits and transport properties of compounds with fluorite structure in the system $\mathrm{ZrO}_{2}-\mathrm{TiO}_{2}-\mathrm{Y}_{2} \mathrm{O}_{3}$ and compared their data with data published in literature. They proposed that discrepancies could be due to temperature fluctuations and/or differences in cooling rates.

In this context the objective of this work was to study the phase and microstructural evolution during reaction sintering of equimolar mixtures of $\mathrm{TiO}_{2}$, and $\mathrm{ZrO}_{2}$ stabilized with $3 \mathrm{~mol} \%$ of $\mathrm{Y}_{2} \mathrm{O}_{3}\left(50 \mathrm{~mol} \% \mathrm{TiO}_{2}, 48.5 \mathrm{~mol} \% \mathrm{ZrO}_{2}, 1.5 \mathrm{~mol} \%\right.$ $\mathrm{Y}_{2} \mathrm{O}_{3}$ ), to establish the basis to design suitable thermal treatments for materials in the $\mathrm{ZrO}_{2}\left(\mathrm{Y}_{2} \mathrm{O}_{3}\right)-\mathrm{TiO}_{2}$ system. In a previous work the rheological behaviours of aqueous slips of the powders and their mixture were studied in order to establish the optimum processing conditions to get high green density bodies by casting of stable slips in plaster moulds ${ }^{19}$.

\section{Experimental}

Commercial $\mathrm{ZrO}_{2}$ stabilized with $3 \mathrm{~mol} \%$ of $\mathrm{Y}_{2} \mathrm{O}_{3}$ (yttria-tetragonal zirconia polycrystal Y-TZP, TZ3YS, TOSOH, Tokyo, Japan) and anatase-TiO 2 (Merck, 808, Darmstadt, Germany) were used as precursor powders. These powders have average particle diameters of 0.4 and $0.3 \mu \mathrm{m}$, respectively, and specific surface areas of 6.7 and $9.0 \mathrm{~m}^{2} / \mathrm{g}$, respectively. 
The particle size distribution was determined with a laser diffraction analyser (Mastersizer S, Malvern, Worcestershire, United Kingdom), and the specific surface area was measured by the $\mathrm{N}_{2}$ adsorption method (Monosorb Surface Area Analyser MS13, Quantachrome Co., Florida, USA).

Concentrated suspensions of Y-TZP $(\mathrm{Z})$ and $\mathrm{TiO}_{2}(\mathrm{~T})$ were prepared separately to 45 vol.\% solids by adding the powder to the proper amount of deionised water containing 0.8 wt.\% of polyacrylic-based dispersant (Dolapix CE64, ZschimmerSchwarz, Lahnstein, Germany) and further mixing with a high shear mixer (Silverson, L2R, Chesham, United Kingdom). Then, they were ball milled for 24 hours using alumina jar and balls. The so-prepared one component suspensions were then mixed in a molar ratio 1:1 (i.e. 60.58 wt.\% $\mathrm{Z}$ and 39.42 wt.\% $\mathrm{T}$ ) in order to obtain ZT50 materials. The resulting mixture was ball milled further for $1 \mathrm{~h}$. Details of the preparation procedure are given in a previous work ${ }^{19}$.

The green bodies shaped into plates of $70 \times 70 \times 10 \mathrm{~mm}^{3}$ were prepared by slip casting the Z, T and ZT50 suspensions in plaster moulds and dried in air for $48 \mathrm{~h}$. Specimens for the different tests were obtained by cutting these plates.

Constant heating rate $\left(\mathrm{CHR}\right.$, heating and cooling rates $\left.5^{\circ} \mathrm{C} / \mathrm{min}\right)$ experiments up to $1600^{\circ} \mathrm{C}$ were performed in a differential dilatometer with alumina rod (Adamel Lhomargy, DI24, Brie France) and in a differential thermal and thermogravimetric analyser (STA 409, Netzsch, Selb, Germany, DTA-TG). From the results of the dilatometer and DTA-TG analyses of ZT50, the temperatures of interest were selected (1400 and $1500^{\circ} \mathrm{C}$ on heating and $1000^{\circ} \mathrm{C}$ on cooling) and specimens were prepared by quenching from those temperatures. The experimental process to get the 1400 and $1500^{\circ} \mathrm{C}$ quenched specimens consisted in heating at $5^{\circ} \mathrm{C} / \mathrm{min}$ to the final temperature, a dwell of $1 \mathrm{~min}$ at the maximum temperature and then quenching to room temperature; 
the $1000^{\circ} \mathrm{C}$ specimen was heated at $5^{\circ} \mathrm{C} / \mathrm{min}$ to $1500^{\circ} \mathrm{C}$ where it was kept during $1 \mathrm{~min}$ before being cooled at $5^{\circ} \mathrm{C} / \mathrm{min}$ to $1000^{\circ} \mathrm{C}$ where it was kept during $1 \mathrm{~min}$ before being quenched. Quenching was performed in air stream using a hair drier, this cooling method, traditionally used in phase equilibrium diagram building, assures cooling times from the treatment temperature to $800^{\circ} \mathrm{C}$ of less than one min for the small $(\approx$ $5 \times 5 \times 5 \mathrm{~mm}^{3}$ ) specimens used.

The quenched specimens were characterised as pieces by X-ray diffraction (XRD) using a Siemens D5000 diffractometer (Munich, Germany) and Si as internal standard. The obtained XRD patterns were analysed using the diffraction files of $\mathrm{ZrTiO}_{4}$ (ASTM 34-415), $\mathrm{Zr}_{5} \mathrm{Ti}_{7} \mathrm{O}_{24}$ (ASTM 34-209), $\mathrm{Zr}_{0.963} \mathrm{Y}_{0.037} \mathrm{O}_{1.982}$ (ASTM 83-113), $\mathrm{r}_{-} \mathrm{TiO}_{2}$ (ASTM 21-1276), $\mathrm{Zr}_{0.62} \mathrm{Y}_{0.20} \mathrm{Ti}_{0.18} \mathrm{O}_{1.90}{ }^{15}$ and $\mathrm{Si}$ (ASTM 77-2111).

The microstructures of diamond polished (down to $3 \mu \mathrm{m}$ ) samples were characterized by field emission gun-scanning electron microscopy with energy dispersive X-ray microanalysis (FE-SEM-EDX, Hitachi S-4700 type I, Tokyo, Japan). Additional FE-SEM characterization was done on fracture surfaces of materials quenched from 1400 and $1500^{\circ} \mathrm{C}$ to complete the phase identification done on the polished specimens that did not allow the complete identification of existing phases.

Two materials named ZT501500 and ZT501500-30h were prepared using thermal treatments of $2 \mathrm{~h}$ and $30 \mathrm{~h}$, respectively, at $1500^{\circ} \mathrm{C}$ and the same heating and cooling rates $\left(5^{\circ} \mathrm{C} / \mathrm{min}\right)$ and characterized by $\mathrm{XRD}$ and FE-SEM-EDX. The microstructural characterization by FE-SEM-EDX of these materials was carried out in polished (down to $3 \mu \mathrm{m})$ and thermally etched $\left(1400^{\circ} \mathrm{C}\right.$ for $1 \mathrm{~min}$, heating and cooling rates of $5^{\circ} \mathrm{C} / \mathrm{min}$ ) surfaces. Additional characterization was done on fracture surfaces of these materials to assure the phase identification done on the polished and thermally 
etched specimens. Observations of un-etched polished surfaces did not allow the complete identification of existing phases.

Raman determinations of ZT501500 and ZT501500-30h on polished and thermally etched at $1400^{\circ} \mathrm{C}$ specimens were performed in backscattering configuration at room temperature (RT) in a DILOR XY spectrometer (Lille, France) with a liquidnitrogen cooled Charge-Coupled Device (CCD) detector and excitation through the 100X objective lens of a microscope (Olympus, BH2, Tokyo, Japan). To improve spatial resolution a confocal diaphragm was inserted at the laser path. With this setup spatial resolution was of about $1 \mu \mathrm{m}$. The $514.5 \mathrm{~nm}$ line of an $\mathrm{Ar}^{+}$laser was used as light source (Coherent, Innova 305C, Santa Clara, California, USA).

\section{Results and Discussion}

\subsection{Reaction sintering process}

Results from the CHR experiments are plotted in figures 1-3. No special features were observed in the shrinkage curve of Z (Fig. 1), accordingly, only one peak corresponding to the progressive sintering process was observed in the derivative one (Fig. 2); shrinkage started at $\approx 1100^{\circ} \mathrm{C}$ and was arrested at $\approx 1550^{\circ} \mathrm{C}$. Conversely, the shrinkage curve of $\mathrm{T}$ (Fig. 1) showed two significant slope changes that were highlighted in the derivative curve (Fig. 2). The first one, at intermediate temperatures, revealed a process occurring at about $1060^{\circ} \mathrm{C}$ that accelerated shrinkage. This process can be identified as the transformation of anatase to rutile, which involves a sudden shrinkage of about 8.5 vol.\% (calculated using the theoretical densities of anatase- $\mathrm{TiO}_{2}$, $3.89 \mathrm{~g} / \mathrm{cm}^{3}$, and rutile- $\mathrm{TiO}_{2}, 4.25 \mathrm{~g} / \mathrm{cm}^{3}$, extracted from ASTM files 21-1272 and 211276). This transformation occurs between $400-1200^{\circ} \mathrm{C}$ depending on several

parameters, such as grain size, impurities and atmosphere ${ }^{20-22}$. The second slope change 
$\left(\approx 1220^{\circ} \mathrm{C}\right)$ corresponded to maximum shrinkage rate and it was wider than the previous one indicating a progressive process, as in the case of Z. Shrinkage was arrested at $\approx 1400^{\circ} \mathrm{C}$ for $\mathrm{T}$.

The initiation of shrinkage of the mixture ZT50 ( $\left.1000^{\circ} \mathrm{C}\right)$ (Fig. 1), was significantly delayed with respect to that of $\mathrm{T}\left(\approx 900^{\circ} \mathrm{C}\right)$ and started at slightly lower temperature than for $\mathrm{Z}\left(\approx 1100^{\circ} \mathrm{C}\right)$. The shrinkage curve showed two slope changes at intermediate temperatures, which were also highlighted in the derivative curve (Fig. 3). For ZT50, the transformation of $\mathrm{TiO}_{2}$ from anatase to rutile produced a sharp acceleration of shrinkage that occurred at a slightly higher temperature $\left(\approx 1100^{\circ} \mathrm{C}\right)$ than for $\mathrm{T}\left(\approx 1060^{\circ} \mathrm{C}\right)$ and was less pronounced because of the smaller amount of $\mathrm{TiO}_{2}$ in the ZT50 composition. The anatase-rutile transformation is not detected by DTA (Fig. 3) due to the low enthalpy change associated $\left(\Delta \mathrm{H}^{0}{ }_{971}=-0.78 \pm 0.20 \mathrm{kcal} \mathrm{mol}^{-1}\right.$, according to calculations by Mitsuhashi et $\mathrm{al}^{23}$ ). For higher temperatures, shrinkage of ZT50 continued in a progressive way and was arrested at about $1440^{\circ} \mathrm{C}$, temperature at which a clear endothermic peak was observed in the DTA curve (Fig.3). In principle, both features, the shrinkage arrest and the endothermic peak could be associated to the formation of the high temperature phase of zirconium titanate, $\mathrm{ZrTiO}_{4}$, with a formation enthalpy of $11.64 \mathrm{~kJ} / \mathrm{mol}$ at $1440^{\circ} \mathrm{C}^{3}$ and which formation from the reaction of tetragonal zirconia (density $=6.07 \mathrm{~g} / \mathrm{cm}^{3}$, ASTM 83-113) and rutile (density $=4.25 \mathrm{~g} / \mathrm{cm}^{3}$, ASTM $21-1276)$ is slightly expansive $(\approx 2.4$ vol.\%). In order to analyse this process, 1400 and $1500^{\circ} \mathrm{C}$ were selected as quenching temperatures.

The DTA curve registered during cooling (Fig. 3) showed an exothermic peak at $\approx 1150^{\circ} \mathrm{C}$, that would correspond to the transition between high-temperature form $\left(\mathrm{ZrTiO}_{4}\right)$ and low-temperature form $\left(\mathrm{Zr}_{5} \mathrm{Ti}_{7} \mathrm{O}_{24}\right)^{9,11,24}$ of zirconium titanate. In order to 
analyse this process, samples treated up to $1500^{\circ} \mathrm{C}$ and cooled down to $1000^{\circ} \mathrm{C}$ were also selected for quenching.

XRD patterns of the quenched samples are shown in figure 4 and SEM micrographs are shown in figures 5-8. In the specimens quenched from $1400^{\circ} \mathrm{C}$, the crystalline phases detected by XRD were rutile $\left(\mathrm{r}-\mathrm{TiO}_{2}\right)$ and tetragonal zirconia $\left(\mathrm{t}-\mathrm{ZrO} \mathrm{r}_{2}\right)$ (Fig. 4a), in agreement with the biphasic microstructure observed in the polished surfaces FE-SEM (Fig. 5), in which the two phases appeared highly interpenetrated. The semi-quantitative analysis by EDX was not possible due to the small size of the areas occupied by the phases in the samples quenched from $1400^{\circ} \mathrm{C}$, nevertheless the EDX diagrams allowed to identify the gray coloured areas as $\mathrm{TiO}_{2}$ and the white ones as $\mathrm{ZrO}_{2}$ (Fig.5). In agreement, the XRD patterns showed the $\mathrm{t}-\mathrm{ZrO}_{2}$ displaced towards higher angles with respect to the $\mathrm{Zr}_{0.963} \mathrm{Y}_{0.037} \mathrm{O}_{1.982}$ pattern, which could be due to the solid solution of $\mathrm{TiO}_{2}$ in $\mathrm{t}-\mathrm{ZrO}_{2}$. In the specimens quenched from $1400^{\circ} \mathrm{C}, \mathrm{ZrTiO}_{4}$, equilibrium phase already at $1300^{\circ} \mathrm{C}^{16}$, was not formed due to the short periods at 1300 $1400^{\circ} \mathrm{C}$ involved in the CHR experiments, as occurred in the work by Ananta et al. ${ }^{8}$ that did not observe any significant process during $\mathrm{CHR}\left(10^{\circ} \mathrm{C} / \mathrm{min}\right)$ treatments up to $1400^{\circ} \mathrm{C}$. Even though the FE-SEM observations of polished surfaces and the XRD patterns corresponded to a biphasic material, additional observations of the fracture surfaces of specimens quenched from $1400^{\circ} \mathrm{C}$ showed small particles located at the boundaries that corresponded to a minor third phase (fig. 6a), as will be discussed after the Raman determinations.

The FE-SEM microstructure of the specimens quenched from $1500^{\circ} \mathrm{C}$ (Fig. 7) and polished appeared also as biphasic. The semiquantitative EDX analyses of the major phase allowed associating it with $\mathrm{ZrTiO}_{4}$. The peaks that would correspond to $\mathrm{ZrTiO}_{4}$ in the XRD diagrams (Fig. 4) were clearly shifted towards angles higher than 
those of the $\mathrm{ZrTiO}_{4}$ pattern. The possibility of solid solution of $\mathrm{TiO}_{2}$ in $\mathrm{ZrTiO}_{4}$ $\left(\mathrm{ZrTiO}_{4} \mathrm{Ss}\right)$ at $1500^{\circ} \mathrm{C}$ was reported by several authors ${ }^{9,15-17}$. Thus, the gray major phase observed in the specimens quenched from $1500^{\circ} \mathrm{C}$ could be unequivocally identified with $\mathrm{ZrTiO}_{4} \mathrm{ss}$. The EDX semiquantitative analysis of the white areas gave $\mathrm{ZrO}_{2}$ with $\mathrm{TiO}_{2}$ and $\mathrm{Y}_{2} \mathrm{O}_{3}$ in solid solution. The XRD peaks that would correspond to $\mathrm{ZrO}_{2}$ in the specimens quenched from $1500^{\circ} \mathrm{C}\left(2 \theta \approx 30.45^{\circ}, 35.25^{\circ}, 50.65^{\circ}\right.$ and $60.1^{\circ}$, Fig. 4) were extremely shifted towards angles higher than those of $\mathrm{t}-\mathrm{ZrO}_{2}\left(\mathrm{Zr}_{0.963} \mathrm{Y}_{0.037} \mathrm{O}_{1.982}\right.$, ASTM 83-113) and $\mathrm{c}-\mathrm{ZrO}_{2}\left(\mathrm{Zr}_{0.8} \mathrm{Y}_{0.2} \mathrm{O}_{1.9}\right.$, ASTM 82-1246) XRD patterns and close to those of c- $\mathrm{ZrO}_{2}$ with 11.4 wt.\% of $\mathrm{TiO}_{2}$ and 18.0 wt.\% of $\mathrm{Y}_{2} \mathrm{O}_{3}$ in solid solution reported by Feighery et al. ${ }^{15}$. Other authors ${ }^{14}$ have also reported the existence of a solid solution of $\mathrm{TiO}_{2}$ (up to 11.8 wt. \%) and $\mathrm{Y}_{2} \mathrm{O}_{3}$ (up to 12.2 wt. \%) in $\mathrm{c}-\mathrm{ZrO}_{2}$ at $1500^{\circ} \mathrm{C}$. Moreover, the above mentioned peaks were shifted about $0.2^{\circ}$ towards angles higher than those reported by Feighery et al. ${ }^{15}$ which would indicate a higher amount of ions with smaller ionic radius than that of $\mathrm{Zr}^{4+}\left(\mathrm{R}_{\mathrm{i}}=0.80 \AA\right)^{25}$, such as $\mathrm{Ti}^{4+}\left(\mathrm{R}_{\mathrm{i}}=0.68 \AA\right)^{25}$, and/or a lower amount of ions with larger ionic radius than that of $\mathrm{Zr}^{4+}$, such as $\mathrm{Y}^{3+}\left(\mathrm{R}_{\mathrm{i}}=0.93 \AA\right)^{25}$,in agreement with the semiquantitative composition of the white grains (Fig. 7). The presence of $\mathrm{c}-\mathrm{ZrO}_{2} \mathrm{ss}$ in the specimens quenched from $1500^{\circ} \mathrm{C}$ supports the phase relationships proposed by Schaedler et al. ${ }^{16}$ in the isothermal section at $1500^{\circ} \mathrm{C}$. As occurred for the specimens quenched from $1400^{\circ} \mathrm{C}$, a minor third phase appeared in the fracture surfaces of these specimens. In this case the amount of third phase particles was higher and they appeared surrounding the $\mathrm{c}-\mathrm{ZrO}_{2} \mathrm{ss}$ grains (Fig. 6b) as will be discussed also after the Raman determinations.

In the microstructure of polished samples quenched from $1000^{\circ} \mathrm{C}$ during the cooling part of the cycle major (gray) and minor (white) phases of similar compositions as those of specimens quenched from $1500^{\circ} \mathrm{C}$ were detected (Fig. 8). From the XRD 
patterns (Fig. 4), the white secondary phase could also be identified as $\mathrm{c}-\mathrm{ZrO}_{2} \mathrm{ss}$. The main difference between XRD spectra of the specimens quenched from $1500^{\circ} \mathrm{C}$ and $1000^{\circ} \mathrm{C}$ on cooling was the position of the peaks of zirconium titanate (Fig. 4), that were shifted to higher angles, corresponding to those of the low temperature form of zirconium titanate, $\mathrm{Zr}_{5} \mathrm{Ti}_{7} \mathrm{O}_{24}(\mathrm{ASTM} 34-209)$.

\subsection{Materials}

Summarizing the above results, the reaction sintering process of equimolar mixtures of $\mathrm{TiO}_{2}$ and $\mathrm{ZrO}_{2}$ stabilized with $3 \mathrm{~mol} \%$ of $\mathrm{Y}_{2} \mathrm{O}_{3}$ using relatively low heating and cooling rates $\left(5^{\circ} \mathrm{C} / \mathrm{min}\right)$ would produce materials constituted by $\mathrm{Zr}_{5} \mathrm{Ti}_{7} \mathrm{O}_{24}$ as major phase when temperatures higher than $1440^{\circ} \mathrm{C}$ are used. On this basis, the selected temperature for the isothermal treatment to get a zirconium titanate based material was $1500^{\circ} \mathrm{C}$.

The density of the material sintered at $1500^{\circ} \mathrm{C}$ during $2 \mathrm{~h}$ (ZT501500) was $5.02 \pm 0.01 \mathrm{~g} / \mathrm{cm}^{3}$. The XRD pattern of ZT501500 (Fig. 9) shows a biphasic material constituted by $\mathrm{Zr}_{5} \mathrm{Ti}_{7} \mathrm{O}_{24}$ as major phase and $\mathrm{c}-\mathrm{ZrO}_{2} \mathrm{ss}$ as second phase. It was not possible to characterise the microstructure of this material on un-etched polished surfaces. In the fracture surfaces shown in figure 10 three kinds of grains are observed. The largest and darkest ones presented transgranular fracture and constituted the major part of the surface (Fig. 10a). The, smaller and clearer grains presented the characteristic facets of intergranular fracture (Fig. 10). These latter were surrounded by small $(<2 \mu \mathrm{m})$ clear gray grains also surrounded by the fracture (Fig. 10b). These observations show that ZT501500 was constituted by three phases.

In order to reveal the grains of the phases in the polished surfaces, a very short (1 min) thermal etching at high temperature was performed; the obtained microstructure is shown in figure 11. The major phase with dark gray colour in the FE-SEM images 
(Fig. 10a and 11) and zirconium titanate composition (Fig. 11b) could be identified as the $\mathrm{Zr}_{5} \mathrm{Ti}_{7} \mathrm{O}_{24}$ observed by XRD (Fig. 9). The second phase formed by relatively large grains $(\approx 3-5 \mu \mathrm{m})$, clearer in the FE-SEM images (Fig. 10a and 11$)$, was identified with $\mathrm{c}-\mathrm{ZrO}{ }_{2} \mathrm{ss}$, in agreement with its composition and the XRD pattern of the material. The minor third phase constituted by small $(<2 \mu \mathrm{m})$ white grains that was found surrounding the $\mathrm{c}-\mathrm{ZrO}_{2} \mathrm{ss}$ grains in the fracture surfaces (Fig. 10b) was clearly revealed by the thermal etching (Fig. 11). Semiquantitative analysis by EDX (Fig. 11b) showed that this minor phase was $\mathrm{Y}_{2} \mathrm{O}_{3}$-richer than the major ones. In order to clarify the nature of this phase, Raman measurements were performed. Due to the triphasic character of this material, spectra were recorded by focusing the laser either into the major phase, identified as $\mathrm{Zr}_{5} \mathrm{Ti}_{7} \mathrm{O}_{24}$, or onto the second phase, identified as a c- $\mathrm{ZrO}_{2} \mathrm{ss}$. The microcrystals of the minor third phase appearing at the boundary of the second phase grains could be seen through the optical microscope of the Raman spectrometer. However, their size was too small to be sure that the spectrum came from only one of such microcrystals. Even inserting a confocal diaphragm to limit the field depth, the scattering volume collected was much larger than the microcrystal. Thus, the indentification could only be performed by indirect means.

Figure 12 shows the Raman spectra of the material sintered at $1500^{\circ} \mathrm{C} 2 \mathrm{~h}$ (ZT501500). The spectrum of the major phase (Fig. 12a) corresponded to that of $\mathrm{Zr}_{5} \mathrm{Ti}_{7} \mathrm{O}_{24}{ }^{26}$ and was unpolarized, in agreement with the expected depolarization of light in polycrystalline samples. When the laser was focused at the separation between the major and the second phases, where the microcrystals of the minor third phase were located, the spectrum (Fig. 12b) presented several differences compared to that of the matrix (Fig. 12a). The most important was the appearance of clear polarization rules, which implies that the laser was impinging on a single crystal area. However, the band 
positions and general aspect of the spectrum were very similar to that of the major phase $\left(\mathrm{Zr}_{5} \mathrm{Ti}_{7} \mathrm{O}_{24}\right)$ (Fig. 13a), except for minor frequency shifts in the region of $400 \mathrm{~cm}^{-1}$.

A spectrum of a microcrystal of the minor third phase was tried to isolate through the following procedure (Fig. 13). Firstly, an area with large concentration of microcrystals was identified, and the laser was focused just at the surface of the material, so that the spectrum measured in that condition had maximum intensity. Strong polarization properties were found, indicating that the contribution of the microcrystals was important. Then, the sample holder was moved downward by steps, setting the laser out of focus and thus collecting a much wider area than in the optimal conditions. The spectrum resembled more and more that of the major phase $\left(\mathrm{Zr}_{5} \mathrm{Ti}_{7} \mathrm{O}_{24}\right)$, and polarization disappeared. The spectrum coming from the microcrystals was obtained by subtracting, with the appropriate factors, the out-of-focus spectrum from the optimal one. In that way, a very simple spectrum with high intensity in the $330 \mathrm{~cm}^{-1}$ region was obtained (Fig. 13). This region is typical of many Ti pyrochlores, though at slightly higher frequency ${ }^{27}$. The compositions of the regions containing the microcrystals (Fig. 11) would further support the microcrystals to be formed by $\mathrm{Ti}$ pyrochlores as suggested by the results of the Raman analyses.

The experimental isothermal section at $1500^{\circ} \mathrm{C}$ reported by Schaedler et al. ${ }^{16}$ shows that pyrochlore and zirconium titanate are not compatible, being $\mathrm{c}-\mathrm{ZrO}_{2}$ and zirconium titanate the compatible phases at $1500^{\circ} \mathrm{C}$. On the contrary, Feighery et al. ${ }^{15}$ reported a isothermal section where pyrochlore and zirconium titanate are compatible at $1500^{\circ} \mathrm{C}$. In order to verify whether pyrochlore is an equilibrium phase at $1500^{\circ} \mathrm{C}$ in the composition studied here, additional specimens were fabricated by sintering at $1500^{\circ} \mathrm{C}$ during 30h; the density of these specimens (ZT501500-30h) was $4.94 \pm 0.05 \mathrm{~g} / \mathrm{cm}^{3}$. The two crystalline phases, $\mathrm{Zr}_{5} \mathrm{Ti}_{7} \mathrm{O}_{24}$ and c- $\mathrm{ZrO}_{2}$ ss were identified by XRD (Fig. 14) in this 
material. FE-SEM observations on fracture surfaces (Fig. 15) and polished and thermally etched surfaces (Fig. 16) of this material, did not allow to discern any minor phase surrounding the $\mathrm{c}-\mathrm{ZrO}_{2} \mathrm{ss}$ grains like in the material ZT501500 (Fig. 10 and 11), which would indicate that pyrochlore is not an equilibrium phase at $1500^{\circ} \mathrm{C}$, in agreement with the Raman observations discussed below and the results of Schaedler et al. ${ }^{16}$. Figure 17 shows Raman spectra of the material treated at $1500^{\circ} \mathrm{C}$ for $30 \mathrm{~h}$ (ZT501500-30h). The spectrum of the major phase showed no polarization and, as in the material annealed for $2 \mathrm{~h}$, corresponded to $\mathrm{Zr}_{5} \mathrm{Ti}_{7} \mathrm{O}_{24}$. The spectrum of the boundary between the major and the second phase showed some polarization degree, but it was much weaker than in the material annealed for $2 \mathrm{~h}$. Thus, if microcrystals of the minor third phase were present in material annealed for $30 \mathrm{~h}$, they had a negligible contribution in terms of volume content.

One final aspect to comment about Raman measurements is the total impossibility to detect a spectrum that could be assigned to tetragonal or cubic zirconia in these materials. In the case of $\mathrm{t}-\mathrm{ZrO}_{2}$, the non-detection of its spectrum means that this phase was not present in these materials, since it is a very active Raman scatterer. The situation with $\mathrm{c}-\mathrm{ZrO}_{2} \mathrm{ss}$ is different, since this phase is only formed by extensive doping, which makes it very defective. Its spectrum, in consequence, is weak and presents very broad bands which might be difficult to detect if they were overlapped with another intense spectrum as in the case of $\mathrm{Zr}_{5} \mathrm{Ti}_{7} \mathrm{O}_{24}$. This situation might be more complicated if $\mathrm{c}-\mathrm{ZrO}_{2}$ phase contains a large amount of $\mathrm{TiO}_{2}$ and $\mathrm{Y}_{2} \mathrm{O}_{3}$ in solid solution as in ZT501500 and ZT501500-30h materials.

From the above discussion, it is clear that the pyrochlore particles observed surrounding the $\mathrm{c}-\mathrm{ZrO}_{2} \mathrm{SS}$ grains in the material treated at $1500^{\circ} \mathrm{C}$ during $2 \mathrm{~h}$ are metastable. However, small pyrochlore particles were clearly observed surrounding the 
zirconia grains in the specimens quenched from $1500^{\circ} \mathrm{C}$ and at some grain boundaries in the specimens quenched from $1400^{\circ} \mathrm{C}$ (Fig. 6), which shows that pyrochlore was formed during the heating treatment up to $1500^{\circ} \mathrm{C}$. This fact can be explained by the extremely low Gibbs free energy of formation of Pyrochlore $\left(-4593 \mathrm{~kJ} / \mathrm{mol}\right.$ at $1000^{\circ} \mathrm{C}$ and $4918 \mathrm{~kJ} / \mathrm{mol}$ at $1500^{\circ} \mathrm{C}$ using the function given by Schaedler et al. ${ }^{16}$ ). It will be easily formed at the grain boundaries between zirconia and titania, even before the reaction of these compounds to form zirconium titanate, with a higher Gibbs free energy in the whole range of temperatures considered $\left(-2292 \mathrm{~kJ} / \mathrm{mol}\right.$ at $1000^{\circ} \mathrm{C}$ and $-2464 \mathrm{~kJ} / \mathrm{mol}$ at $1500^{\circ} \mathrm{C}$ using the function given by Schaedler et al. $\left.{ }^{16}\right)$. Therefore, pyrochlore formed at the grain boundaries of the material studied here during the heating up of the specimens and even at the initial part of the isothermal treatment at $1500^{\circ} \mathrm{C}$, as observed in the specimens quenched from 1400 and $1500^{\circ} \mathrm{C}$ (Fig. 6) and treated at $1500^{\circ} \mathrm{C}$ during $2 \mathrm{~h}$ (Fig. 10 and 11). Longer times at $1500^{\circ} \mathrm{C}$ will allow the progressive reaction of pyrochlore and zirconium titanate to form $\mathrm{c}-\mathrm{ZrO}_{2} \mathrm{Ss}$ and $\mathrm{r}-\mathrm{TiO}_{2}$, reaction which is favourable at $1500^{\circ} \mathrm{C}^{16}$. In fact, an increase in the amount of $\mathrm{c}-\mathrm{ZrO}_{2} \mathrm{ss}$ for the sample treated during $30 \mathrm{~h}$ is qualitatively observed when a comparison between the XRD relative height of the (111) peak $\left(2 \theta \approx 30.45^{\circ}\right)$ of $\mathrm{c}-\mathrm{ZrO}_{2} \mathrm{ss}$ and the (131) peak $\left(2 \theta \approx 30.76^{\circ}\right)$ of $\mathrm{Zr}_{5} \mathrm{Ti}_{7} \mathrm{O}_{24}$ of the samples treated $2 \mathrm{~h}(\approx 0.22)$ and $30 \mathrm{~h}(\approx 0.35)$ are compared. The excess $\mathrm{r}-\mathrm{TiO}_{2}$ produced in this reaction could enter in the structure of $\mathrm{ZrTiO}_{4} \mathrm{ss}$ during cooling to form the low temperature form $\mathrm{Zr}_{5} \mathrm{Ti}_{7} \mathrm{O}_{24}$, or in c- $\mathrm{ZrO}_{2} \mathrm{ss}$.

\section{Conclusions}

The reaction sintering process of equimolar mixtures of $\mathrm{TiO}_{2}$ and $\mathrm{ZrO}_{2}$ stabilised by $3 \mathrm{~mol} \%$ of $\mathrm{Y}_{2} \mathrm{O}_{3}$ to get zirconium titanate based materials, using relatively low 
heating and cooling rates $\left(5^{\circ} \mathrm{C} / \mathrm{min}\right)$ and $1500^{\circ} \mathrm{C}$ as maximum temperature, has been studied.

During the heating part of the cycle $\mathrm{ZrTiO}_{4}$ is formed at $\approx 1440^{\circ} \mathrm{C}$. On cooling, the transition between $\mathrm{ZrTiO}_{4}$ and $\mathrm{Zr}_{5} \mathrm{Ti}_{7} \mathrm{O}_{24}$ occurs at $\approx 1150^{\circ} \mathrm{C}$.

Materials obtained by sintering using $1500^{\circ} \mathrm{C}$ as maximum sintering temperature during $2 \mathrm{~h}$ (relatively short thermal treatment such as those used in conventional ceramic processing), are constituted by $\mathrm{Zr}_{5} \mathrm{Ti}_{7} \mathrm{O}_{24}$ as major phase, a solid solution of $\mathrm{TiO}_{2}$ and $\mathrm{Y}_{2} \mathrm{O}_{3}$ in $\mathrm{c}-\mathrm{ZrO}_{2}$ and pyrochlore as minor phase, which is not an equilibrium phase at $1500^{\circ} \mathrm{C}$.

\section{Acknowledgements}

This work has been supported by the Spanish Ministry of Education and Science under contracts MEC MAT2006-13480 C02-01 and MAT2007-64486 C07-02. E. LópezLópez acknowledges to Community of Madrid (Spain) and European Social Fund for economical support by CPI/0552/2007 contract. 


\section{References}

1. Ikawa H, Iwai A, K. Iruta, Shimojima H, Urabe K. and Udagawa S., Phase transformation and thermal expansion of zirconium and hafnium titanates and their solid solutions, J. Am. Ceram. Soc., 1988, 71, 120-127.

2. Bhattacharya A.K., Mallick K.K., Hartridge A. and Woodhead J. L., Sol gel preparation, structure and thermal satability of crystalline zirconium titanate microspheres. J. Mater. Sci., 1996, 31, 267-271.

3. Hom B. K., Stevens R., Woodfield B. F., Boerio-Goates J., Putnam L., Helean K. B. and Navrotsky A., The thermodynamics of formation, molar heat capacity, and thermodynamic functions of $\mathrm{ZrTiO}_{4}$ (cr). J. Chem. Thermodynamics, 2001, 33, 165-178.

4. Christoffersen R. and Davies P. K., Extended defect intergrowths in $\mathrm{Zr}_{1-\mathrm{x}} \mathrm{Ti}_{1+\mathrm{x}} \mathrm{O}_{4}$. Solid State Ionics, 1992, 57, 59-69.

5. Kim I. J and, Kim H. C., Zero level thermal expansion materials based on $\mathrm{ZrTiO}_{4}-$ $\mathrm{Al}_{2} \mathrm{TiO}_{5}$ ceramics synthesized by reaction sintering. J. Ceram. Proc. Res., 2004, 5, 308312.

6. Vittayakorn N., Synthesis and a crystal structural study of microwave dielectric zirconium titanate $\left(\mathrm{ZrTiO}_{4}\right)$ powders via a mixed oxide synthesis route. J. Ceram. Proc. Res., 2006, 7, 288-291.

7. Licina V., Gajovic A., Mogus-Milankovic A., Djerdj I., Tomasic N. and Su D., Correlation between the microstructe and the electrical properties of $\mathrm{ZrTiO}_{4}$ ceramics. J. Am. Ceram. Soc., 2008, 91, 178-186.

8. Ananta S., Tipakontitikul R. and Tunkasiri T., Synthesis, formation and characterization of zirconium titanate (ZT) powders. Mater. Lett. 2003, 57, 2637-2642.

9. McHale A. E. and Roth R. S., Low-temperature phase relationships in the system $\mathrm{ZrO}_{2}-\mathrm{TiO}_{2}$. J. Am. Ceram. Soc., 1986, 69, 827-832. 
10. Troitzsch U. and Ellis D. J., The $\mathrm{ZrO}_{2}-\mathrm{TiO}_{2}$ phase diagram. J. Mater. Sci. 2005, 40, 4571-4577.

11. Bordet P., McHale A., Santoro A. and Roth R. S., Powder neutron diffraction study of $\mathrm{ZrTiO}_{4}, \mathrm{Zr}_{5} \mathrm{Ti}_{7} \mathrm{O}_{24}$ and $\mathrm{FeNb}_{2} \mathrm{O}_{6}$. J. Solid State Chem., 1986, 64, 30-46.

12. Azough F., Wright A. and Freer R., The microstructure and dielectric properties of $\mathrm{Zr}_{5} \mathrm{Ti}_{7} \mathrm{O}_{24}$ ceramics. J. Solid State Chem. 1994, 108, 284-290.

13. Wang C. L., Lee H. Y., Azough F. and Freer R., The microstructure and microwave dielectric properties of zirconium titanate ceramics in the solid solution system $\mathrm{ZrTiO}_{4}$ $\mathrm{Zr}_{5} \mathrm{Ti}_{7} \mathrm{O}_{24}$ J. Mater. Sci., 1997, 32, 1693-1701.

14. Colomer M. T., Durán P., Caballero A. and Jurado J. R., Microstructure, electrical properties and phase equilibria relationships in the $\mathrm{ZrO}_{2}-\mathrm{Y}_{2} \mathrm{O}_{3}-\mathrm{TiO}_{2}$ system: the subsolidus isothermal section at $1500^{\circ} \mathrm{C}$. Mater. Sci. Eng. A, 1997, 229, 114-122.

15. Feighery A. J., Irvine J. T. S., Fagg D. P. and Kaiser A., Phase relations at $1500^{\circ} \mathrm{C}$ in the ternary system $\mathrm{ZrO}_{2}-\mathrm{Y}_{2} \mathrm{O}_{3}-\mathrm{TiO}_{2}$. J. Solid State Chem., 1999, 143, 273-276.

16. Schaedler T. A., Fabrichnaya O. and Levi C. G., Phase equilibria in the $\mathrm{TiO}_{2}-\mathrm{YO}_{1.5^{-}}$ $\mathrm{ZrO}_{2}$ system. J. Eur. Ceram. Soc., 2008, 28, 2509-2520.

17. Kobayashi K., Kato K., Terabe K., Yamaguchi S. and Iguchi Y., Phase relation of $\mathrm{ZrO}_{2}-\mathrm{YO}_{1.5}-\mathrm{TiO}_{2}$ ceramic prepared by sol-gel method. J. Ceram. Soc. Jpn., 1998, 106, $860-866$.

18. Fagg D. P., Frade J. R., Mogensen M. and Irvine J. T. S., Effects of firing schedule on solubility limits and transport properties of $\mathrm{ZrO}_{2}-\mathrm{TiO}_{2}-\mathrm{Y}_{2} \mathrm{O}_{3}$ fluorites. J. Solid State Chem., 2007, 180, 2371-2376.

19. López-López E., Baudín C. and Moreno R., Synthesis of zirconium titanate based materials by colloidal filtration and reaction sintering. Int. J. Appl. Ceram. Technol., 2008, 5, 394-400. 
20. Shannon R. D. and Pask J. A., Kinetics of the anatase-rutile transformation. J. Am. Ceram. Soc., 1965, 48, 391-398.

21. Gouma P. I. and Mills M. J., Anatase-to-rutile transformation in titania powders. J. Am. Ceram. Soc., 2001, 84, 619-622.

22. Iida Y. and Ozaki S., Grain growth and phase transformation of titanium oxide during calcination. J. Am. Ceram. Soc., 1961, 44, 120-127.

23. Mitsuhashi T. and Kleppa O. J., Transformation enthalpies of the $\mathrm{TiO}_{2}$ polymorphs. J. Am. Ceram. Soc., 1979, 62, 356-357.

24. McHale A. E. and Roth R. S., Investigation of the phase transition in $\mathrm{ZrTiO}_{4}$ and $\mathrm{ZrTiO}_{4}-\mathrm{SnO}_{2}$ solid solutions. J. Am. Ceram. Soc., 1983, 66, C18.

25. Cotton F. A. and Wilkinson G., non molecular solids, page 31 in Advanced Inorganic Chemistry. Ed. Limusa, Mexico, 1996.

26. Azough F., Freer R. and Petzelt J., A Raman spectral characterization of ceramics in the system $\mathrm{ZrO}_{2}-\mathrm{TiO}_{2}$. J. Mater. Sci., 1993, 28, 2273-2276.

27. Glerup M., Nielsen O. F. and Poulsen F. W., The structural transformation from the pyrochlore structure, $\mathrm{A}_{2} \mathrm{~B}_{2} \mathrm{O}_{7}$, to the fluorite structure, $\mathrm{AO}_{2}$, studied by Raman spectroscopy and defect chemistry modeling. J. Solid State Chem., 2001, 160, 25-32. 


\section{Figure Captions}

Figure 1. Shrinkage versus temperature recorded during the heating part of the constant heating rate experiments $\left(5^{\circ} \mathrm{C} / \mathrm{min}\right)$ for the studied compositions $\mathrm{Y}-\mathrm{TZP}(\mathrm{Z}), \mathrm{TiO}_{2}(\mathrm{~T})$ and $50 \mathrm{~mol} \% \mathrm{Z} / 50 \mathrm{~mol} \% \mathrm{~T}(\mathrm{ZT} 50)$.

Figure 2. Derivate versus temperature of the curves plotted in figure 1 for $Z$ and $T$.

Figure 3. Derivative versus temperature of the curve plotted in figure 1 for ZT50 together with the differential thermal analysis (DTA) curves recorded for heating and cooling during the constant heating rate experiments for ZT50.

Figure 4. X-Ray diffraction spectra of ZT50 samples after quenching tests in air from 1400 and $1500^{\circ} \mathrm{C}$ on heating and from $1000^{\circ} \mathrm{C}$ on cooling. Si was used as internal

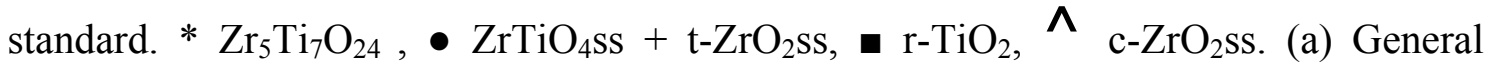
spectra; (b) Detail of the spectra showing the shift of the zirconium titanate $\left(\mathrm{ZrTiO}_{4} \mathrm{Ss}\right)$ and the tetragonal zirconia $\left(\mathrm{t}-\mathrm{ZrO}_{2} \mathrm{ss}\right)$ peaks of the material from $\mathrm{ZrTiO}_{4}$ (ASTM 34415, dashed line) and $\mathrm{Zr}_{0.963} \mathrm{Y}_{0.037} \mathrm{O}_{1.982}$ (ASTM 83-113, solid line), respectively.

Figure 5. Microstructure of ZT50 quenched from $1400^{\circ} \mathrm{C}$ on heating. FE-SEM micrographs of polished surfaces, together with characteristic EDX analyses. Ti and Zr are the major components in the gray and white areas, respectively.

Figure 6. FE-SEM micrographs of fracture surfaces of ZT50 quenched specimens.

a) Specimen quenched from $1400^{\circ} \mathrm{C}$. The phase presenting transgranular fracture is $\mathrm{TiO}_{2}$, the grains with intergranular fracture is $\mathrm{t}-\mathrm{ZrO}_{2}$ and the small grains observed at the boundaries of these grains can be associated with pyrochlore.

b) Specimen quenched from $1500^{\circ} \mathrm{C}$. It is not possible to distinguish the major phase (Fig. 4 and 7). Small angular grains of pyrochlore are observed.

Figure 7. Microstructure of ZT50 quenched from $1500^{\circ} \mathrm{C}$ on heating. FE-SEM micrographs of polished surfaces, together with characteristic EDX analyses. 
Semiquantitative analyses gave a major phase ( $\approx 62-64$ wt. $\% \mathrm{ZrO}_{2}, 34-36$ wt. $\% \mathrm{TiO}_{2}, 2-$ 3 wt. $\left.\% \mathrm{Y}_{2} \mathrm{O}_{3}\right)$ that could be identified as $\mathrm{ZrTiO}_{4} \mathrm{ss}$, meanwhile the white areas $(\approx 68-70$ wt. $\% \mathrm{ZrO}_{2}, 17-20$ wt. $\% \mathrm{TiO}_{2}, 13-15$ wt. $\% \mathrm{Y}_{2} \mathrm{O}_{3}$ ) should correspond to $\mathrm{c}-\mathrm{ZrO}_{2}$ with a certain amount of $\mathrm{TiO}_{2}$ and $\mathrm{Y}_{2} \mathrm{O}_{3}$ in solid solution.

Figure 8. Microstructure of ZT50 quenched from $1000^{\circ} \mathrm{C}$ on cooling. FE-SEM micrographs of polished surfaces, together with characteristic EDX analyses. Semiquantitative analyses gave a major phase $\left(\approx 59-61\right.$ wt. $\% \mathrm{ZrO}_{2}, 36-38$ wt. $\% \mathrm{TiO}_{2}, 1$ 2 wt. $\left.\% \mathrm{Y}_{2} \mathrm{O}_{3}\right)$ that could be identified as $\mathrm{Zr}_{5} \mathrm{Ti}_{7} \mathrm{O}_{24}$, meanwhile the white areas $(\approx 68-71$ wt. $\% \mathrm{ZrO}_{2}, 16-18$ wt.\% $\mathrm{TiO}_{2}, 12-14$ wt. $\% \mathrm{Y}_{2} \mathrm{O}_{3}$ ) should correspond to $\mathrm{c}-\mathrm{ZrO}_{2}$ with a certain amount of $\mathrm{TiO}_{2}$ and $\mathrm{Y}_{2} \mathrm{O}_{3}$ in solid solution.

Figure 9. X-Ray diffraction pattern of the composites ZT50 sintered at $1500^{\circ} \mathrm{C} / 2 \mathrm{~h}$. ${ }^{*}$ $\mathrm{Zr}_{5} \mathrm{Ti}_{7} \mathrm{O}_{24}, \bigwedge_{\mathrm{c}-\mathrm{ZrO}_{2} \mathrm{ss}}$

Figure 10. Microstructure of the composite ZT50 sintered at $1500^{\circ} \mathrm{C} / 2 \mathrm{~h}$. FE-SEM micrographs of fracture surfaces. The major phase, dark gray, presents transgranular fracture and was identified as $\mathrm{Zr}_{5} \mathrm{Ti}_{7} \mathrm{O}_{24}$ (Fig. 11). The secondary phase, light gray, that presents intergranular fracture was identified as $\mathrm{c}-\mathrm{ZrO}_{2}$ (Fig. 11). Small grains surrounding this phase were identified as pirochlore (Fig. 11).

Figure 11. Microstructure of the composites ZT50 sintered at $1500^{\circ} \mathrm{C} / 2 \mathrm{~h}$. FE-SEM micrographs of polished and thermally etched $\left(1400^{\circ} \mathrm{C} / 1 \mathrm{~min}\right)$ surfaces, together with characteristic EDX analyses. Semiquantitative analyses gave a major phase $(\approx 53-57$ wt. $\% \mathrm{ZrO}_{2}, 41-43$ wt. $\% \mathrm{TiO}_{2}, 2-3 \%$ wt. $\% \mathrm{Y}_{2} \mathrm{O}_{3}$ ) that could be identified as $\mathrm{Zr}_{5} \mathrm{Ti}_{7} \mathrm{O}_{24}$, meanwhile the second phase $\left(\approx 62-64\right.$ wt. $\% \mathrm{ZrO}_{2}, 14-18$ wt.\% $\mathrm{TiO}_{2}, 19-23 \%$ wt.\% $\mathrm{Y}_{2} \mathrm{O}_{3}$ ) should correspond to c- $\mathrm{ZrO}_{2}$ with a certain amount of $\mathrm{TiO}_{2}$ and $\mathrm{Y}_{2} \mathrm{O}_{3}$ in solid solution, and the minor third phase $\left(\approx 40-45\right.$ wt. $\% \mathrm{ZrO}_{2}, 27-33$ wt.\% $\mathrm{TiO}_{2}, 24-30$ wt.\% $\mathrm{Y}_{2} \mathrm{O}_{3}$ ) should be pyrochlore 
Figure 12. Raman spectra of composites ZT50 sintered at $1500^{\circ} \mathrm{C} / 2 \mathrm{~h}$. (a) Spectra of the major phase $\left(\mathrm{Zr}_{5} \mathrm{Ti}_{7} \mathrm{O}_{24}\right)$; (b) Spectra of the microcrystals of the minor third phase. ( $\mathrm{x}$ crossed configuration, // parallel configuration).

Figure 13. Raman spectra in focus, out of focus and weighted difference, of the microcrystals of the minor third phase in composites ZT50 sintered at $1500^{\circ} \mathrm{C} / 2 \mathrm{~h}$.

Figure 14. X-Ray diffraction pattern of the composites ZT50 sintered at $1500^{\circ} \mathrm{C} / 30 \mathrm{~h}$. * $\mathrm{Zr}_{5} \mathrm{Ti}_{7} \mathrm{O}_{24}, \wedge_{\mathrm{c}-\mathrm{ZrO}_{2} \mathrm{ss}}$

Figure 15. Microstructure of the composite ZT50 treated at $1500^{\circ} \mathrm{C} / 30 \mathrm{~h}$. FE-SEM micrographs of fracture surfaces. The phase that presents transgranular fracture was identified as $\mathrm{Zr}_{5} \mathrm{Ti}_{7} \mathrm{O}_{24}$ (Fig. 16). The grains that present intergranular fracture were identified as c- $\mathrm{ZrO}_{2}$ (Fig. 16).

Figure 16. Microstructure of the composites ZT50 sintered at $1500^{\circ} \mathrm{C} / 30 \mathrm{~h}$. FE-SEM micrographs of polished and thermally etched $\left(1400^{\circ} \mathrm{C} / 1 \mathrm{~min}\right)$ surfaces, together with characteristic EDX analyses. Semiquantitative analyses gave a major phase ( $\approx 61-63$ wt. $\% \mathrm{ZrO}_{2}, 33-35$ wt. $\% \mathrm{TiO}_{2}, 1-3 \%$ wt. $\% \mathrm{Y}_{2} \mathrm{O}_{3}$ ) that could be identified as $\mathrm{Zr}_{5} \mathrm{Ti}_{7} \mathrm{O}_{24}$, meanwhile the second phase ( $\approx 64-66$ wt. $\% \mathrm{ZrO}_{2}, 10-12$ wt.\% $\mathrm{TiO}_{2}, 23-25$ wt. $\% \mathrm{Y}_{2} \mathrm{O}_{3}$ ) should correspond to c- $\mathrm{ZrO}_{2}$ with a certain amount of $\mathrm{TiO}_{2}$ and $\mathrm{Y}_{2} \mathrm{O}_{3}$ in solid solution. Figure 17. Raman spectra of composites ZT50 sintered at $1500^{\circ} \mathrm{C} / 30 \mathrm{~h}$. (a) Spectra of the major phase $\left(\mathrm{Zr}_{5} \mathrm{Ti}_{7} \mathrm{O}_{24}\right)$; (b) Spectra of the boundary of the second phase (x crossed configuration, // parallel configuration). 


\section{Figures}

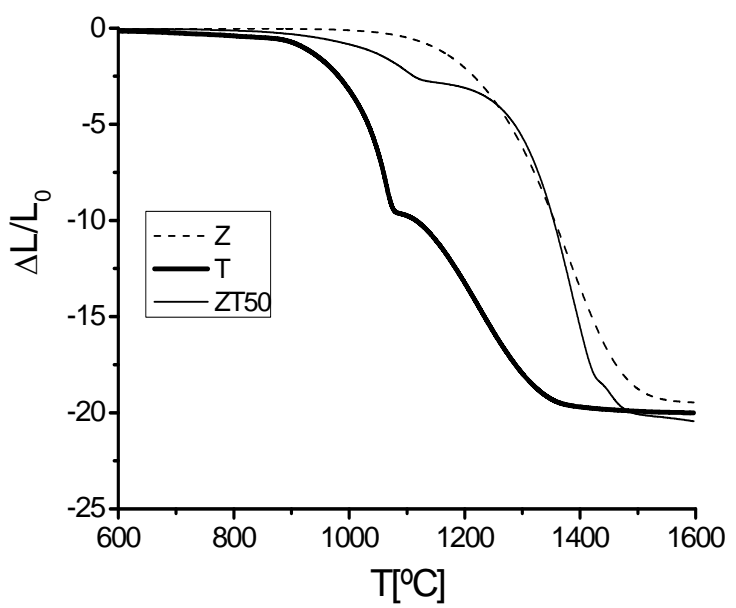

Figure 1. Shrinkage versus temperature recorded during the heating part of the constant heating rate experiments $\left(5^{\circ} \mathrm{C} / \mathrm{min}\right)$ for the studied compositions $\mathrm{Y}-\mathrm{TZP}(\mathrm{Z}), \mathrm{TiO}_{2}(\mathrm{~T})$ and 50 $\mathrm{mol} \% \mathrm{Z} / 50 \mathrm{~mol} \% \mathrm{~T}(\mathrm{ZT} 50)$.

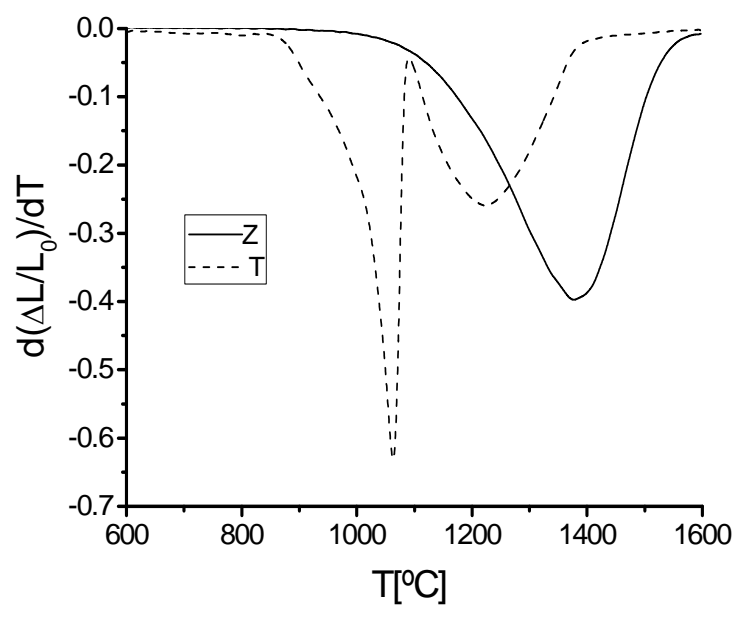

Figure 2. Derivate versus temperature of the curves plotted in figure 1 for $Z$ and $T$. 


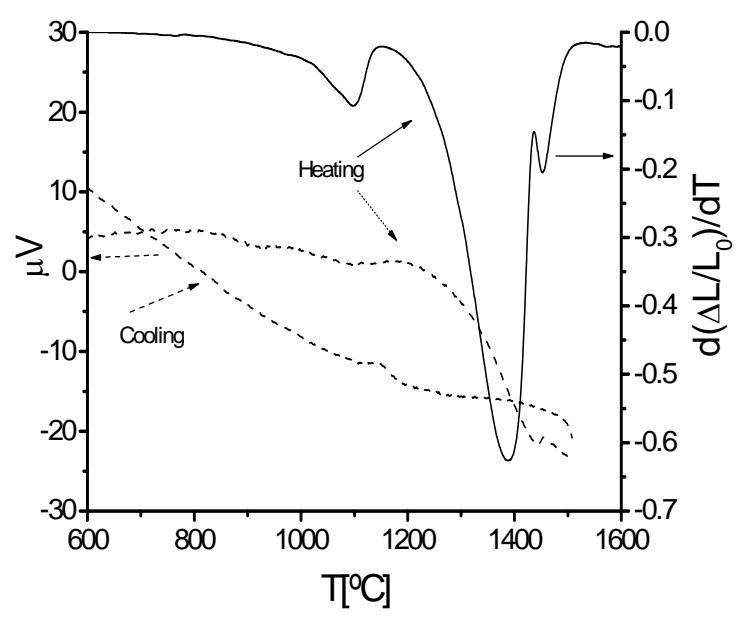

Figure 3. Derivative versus temperature of the curve plotted in figure 1 for ZT50 together with the differential thermal analysis (DTA) curves recorded for heating and cooling during the constant heating rate experiments for ZT50.
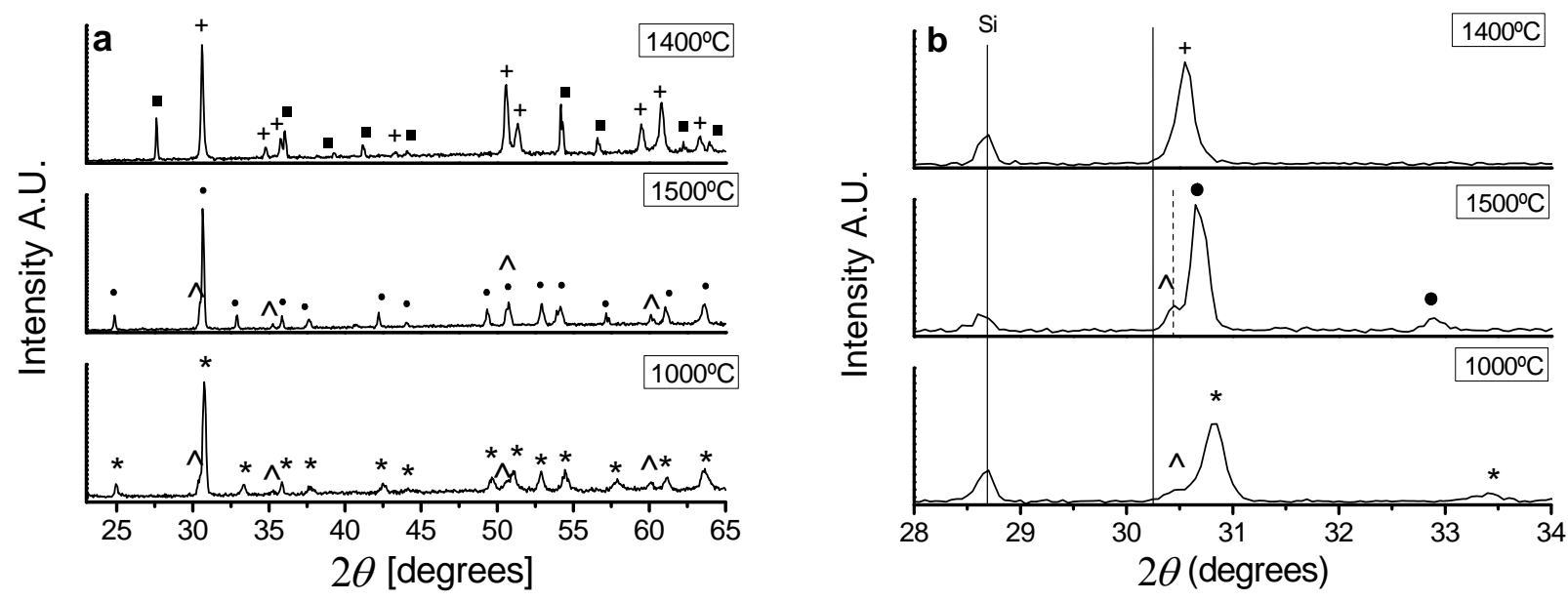

Figure 4. X-Ray diffraction spectra of ZT50 samples after quenching tests in air from 1400 and $1500^{\circ} \mathrm{C}$ on heating and from $1000^{\circ} \mathrm{C}$ on cooling. Si was used as internal standard. $* \mathrm{Zr}_{5} \mathrm{Ti}_{7} \mathrm{O}_{24}, \bullet \mathrm{ZrTiO}_{4} \mathrm{Ss}+\mathrm{t}-\mathrm{ZrO}_{2} \mathrm{ss}$,

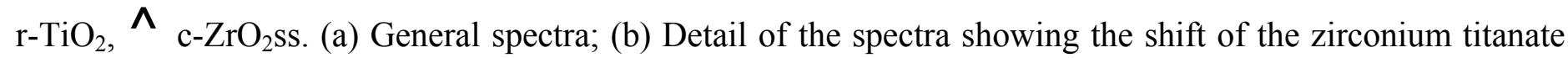
$\left(\mathrm{ZrTiO}_{4} \mathrm{ss}\right)$ and the tetragonal zirconia $\left(\mathrm{t}-\mathrm{ZrO}_{2} \mathrm{ss}\right)$ peaks of the material from $\mathrm{ZrTiO}_{4}$ (ASTM 34-415, dashed line) and $\mathrm{Zr}_{0.963} \mathrm{Y}_{0.037} \mathrm{O}_{1.982}$ (ASTM 83-113, solid line), respectively. 

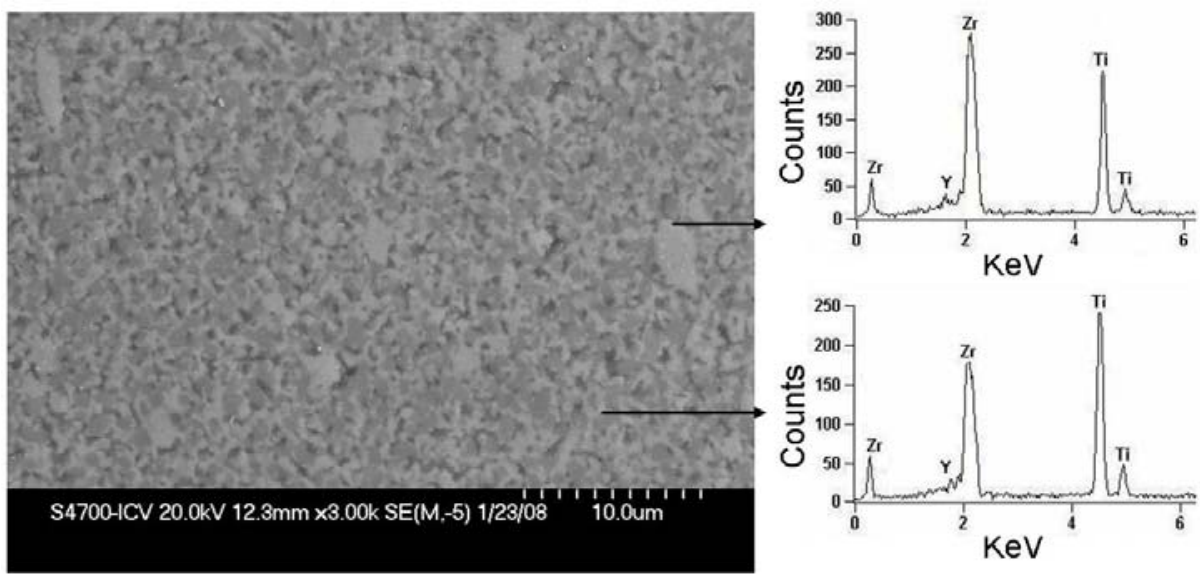

Figure 5. Microstructure of ZT50 quenched from $1400^{\circ} \mathrm{C}$ on heating. FE-SEM micrographs of polished surfaces, together with characteristic EDX analyses. Ti and $\mathrm{Zr}$ are the major components in the gray and white areas, respectively.
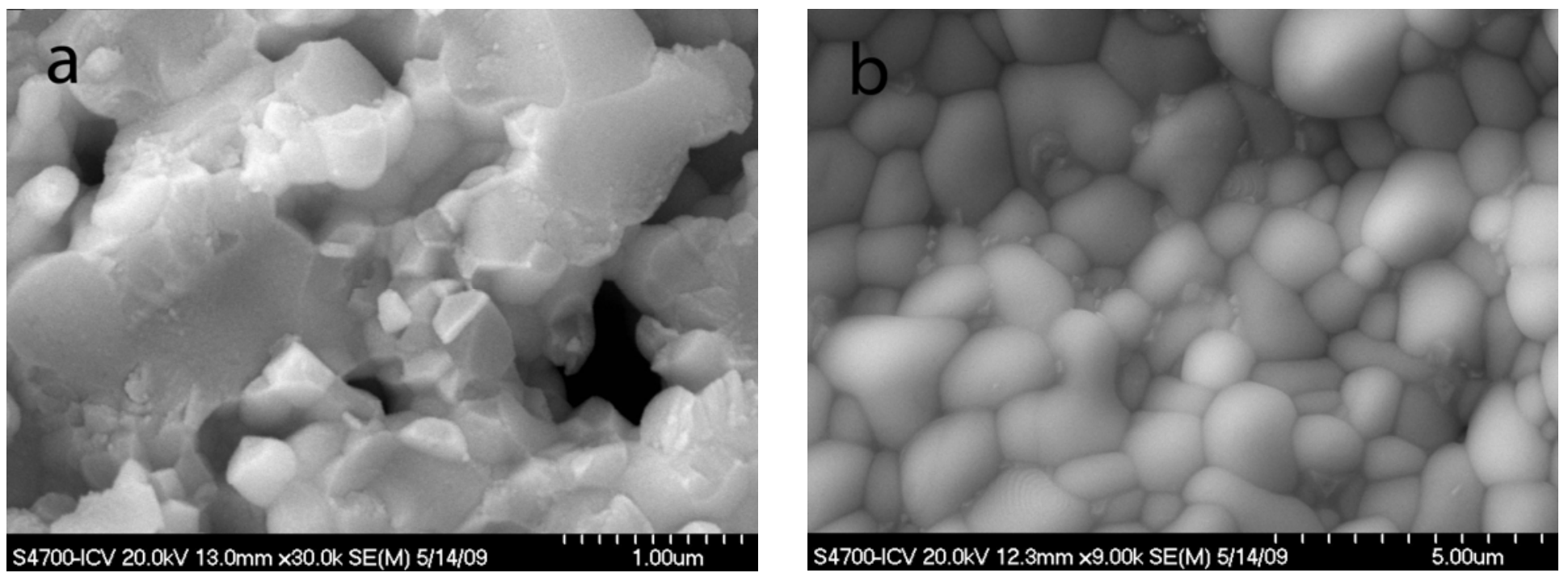

Figure 6. FE-SEM micrographs of fracture surfaces of ZT50 quenched specimens.

a) Specimen quenched from $1400^{\circ} \mathrm{C}$. The phase presenting transgranular fracture is $\mathrm{TiO}_{2}$, the grains with intergranular fracture is $\mathrm{t}-\mathrm{ZrO}_{2}$ and the small grains observed at the boundaries of these grains can be associated with pyrochlore.

b) Specimen quenched from $1500^{\circ} \mathrm{C}$. It is not possible to distinguish the major phase (Fig. 4 and 7 ). Small angular grains of pyrochlore are observed. 


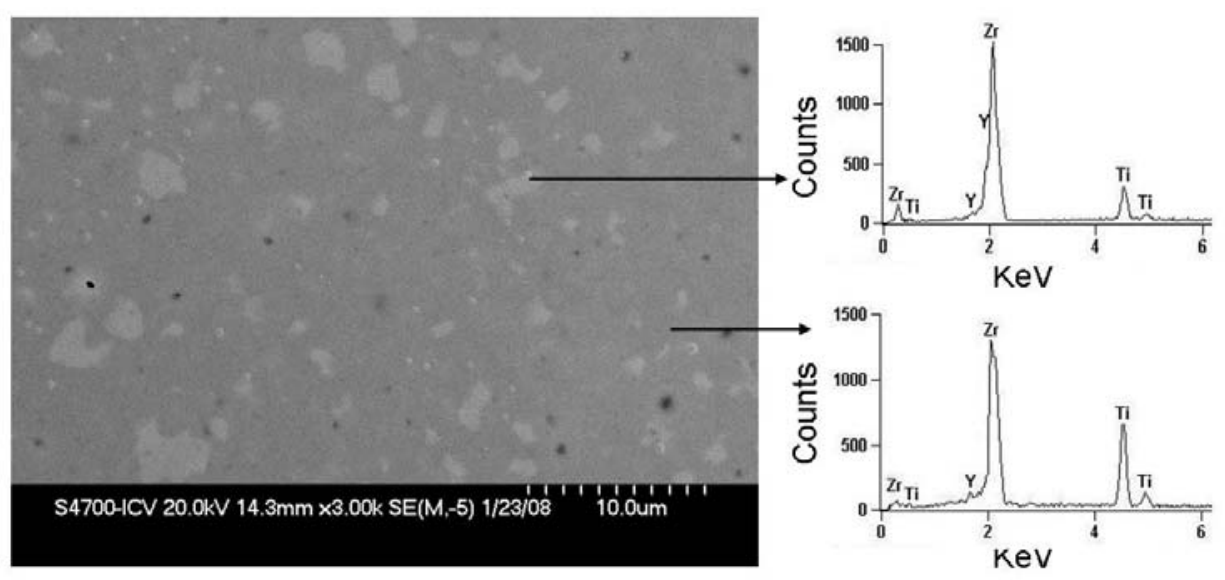

Figure 7. Microstructure of ZT50 quenched from $1500^{\circ} \mathrm{C}$ on heating. FE-SEM micrographs of polished surfaces, together with characteristic EDX analyses. Semiquantitative analyses gave a major phase $\left(\approx 62-64\right.$ wt. $\% \mathrm{ZrO}_{2}, 34-36$ wt.\% $\mathrm{TiO}_{2}, 2-3$ wt.\% $\left.\mathrm{Y}_{2} \mathrm{O}_{3}\right)$ that could be identified as $\mathrm{ZrTiO}_{4} \mathrm{ss}$, meanwhile the white areas $\left(\approx 68-70 \mathrm{wt} . \% \mathrm{ZrO}_{2}, 17-20 \mathrm{wt} . \% \mathrm{TiO}_{2}, 13-15 \mathrm{wt} . \% \mathrm{Y}_{2} \mathrm{O}_{3}\right)$ should correspond to c- $\mathrm{ZrO}_{2}$ with a certain amount of $\mathrm{TiO}_{2}$ and $\mathrm{Y}_{2} \mathrm{O}_{3}$ in solid solution.

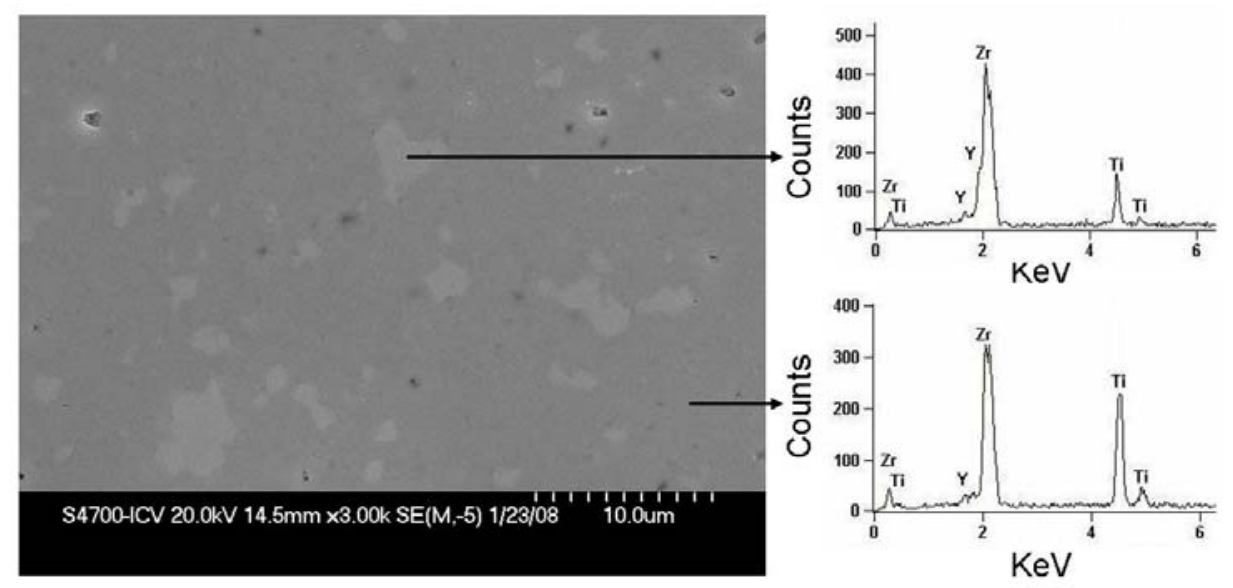

Figure 8. Microstructure of ZT50 quenched from $1000^{\circ} \mathrm{C}$ on cooling. FE-SEM micrographs of polished surfaces, together with characteristic EDX analyses. Semiquantitative analyses gave a major phase $\left(\approx 59-61\right.$ wt. $\% \mathrm{ZrO}_{2}, 36-38$ wt.\% $\mathrm{TiO}_{2}, 1-2$ wt.\% $\left.\mathrm{Y}_{2} \mathrm{O}_{3}\right)$ that could be identified as $\mathrm{Zr}_{5} \mathrm{Ti}_{7} \mathrm{O}_{24}$, meanwhile the white areas $\left(\approx 68-71 \mathrm{wt} . \% \mathrm{ZrO}_{2}, 16-18 \mathrm{wt} . \% \mathrm{TiO}_{2}, 12-14 \mathrm{wt} . \% \mathrm{Y}_{2} \mathrm{O}_{3}\right)$ should correspond to c- $\mathrm{ZrO}_{2}$ with a certain amount of $\mathrm{TiO}_{2}$ and $\mathrm{Y}_{2} \mathrm{O}_{3}$ in solid solution. 


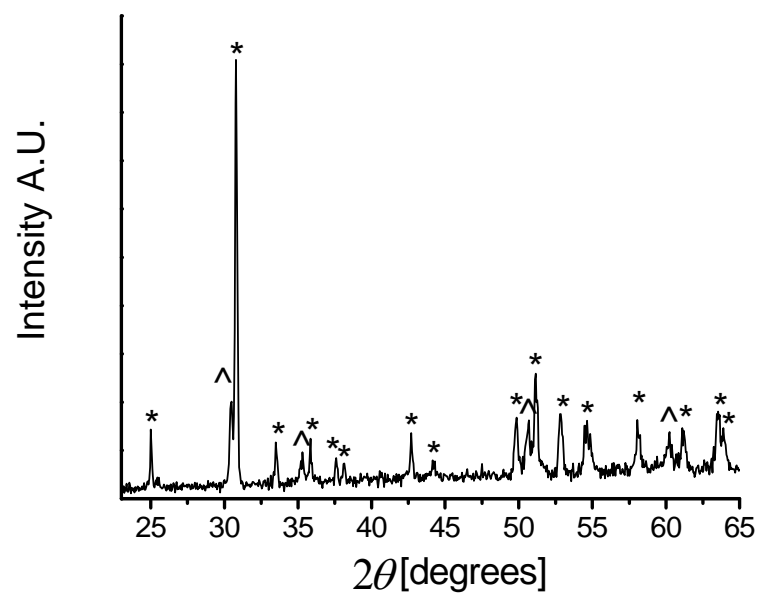

Figure 9. X-Ray diffraction pattern of the composites $\mathrm{ZT} 50$ sintered at $1500^{\circ} \mathrm{C} / 2 \mathrm{~h} .{ }^{*} \mathrm{Zr}_{5} \mathrm{Ti}_{7} \mathrm{O}_{24}$, $\bigwedge_{\mathrm{c}-\mathrm{ZrO}_{2} \mathrm{ss}}$
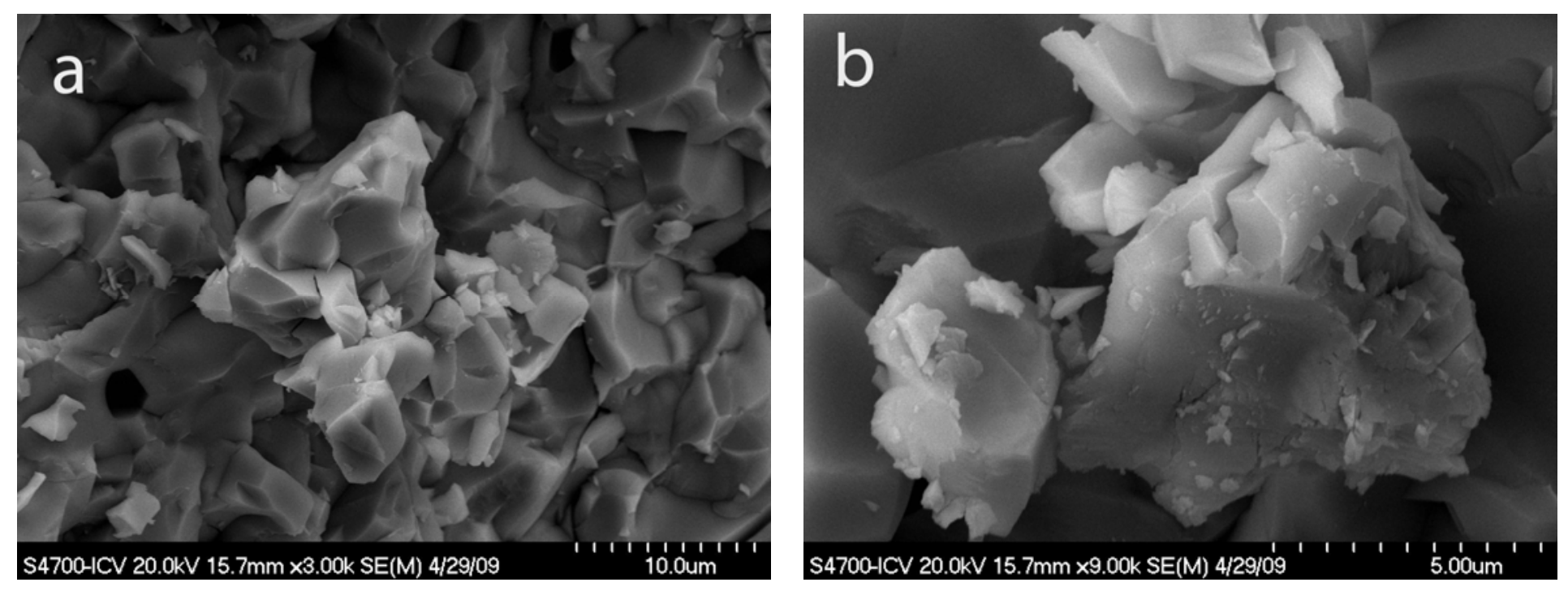

Figure 10. Microstructure of the composite ZT50 sintered at $1500^{\circ} \mathrm{C} / 2 \mathrm{~h}$. FE-SEM micrographs of fracture surfaces. The major phase, dark gray, presents transgranular fracture and was identified as $\mathrm{Zr}_{5} \operatorname{Ti}_{7} \mathrm{O}_{24}$ (Fig. 11). The secondary phase, light gray, that presents intergranular fracture was identified as c- $\mathrm{ZrO}_{2}$ (Fig. 11). Small grains surrounding this phase were identified as pyrochlore (Fig. 11). 

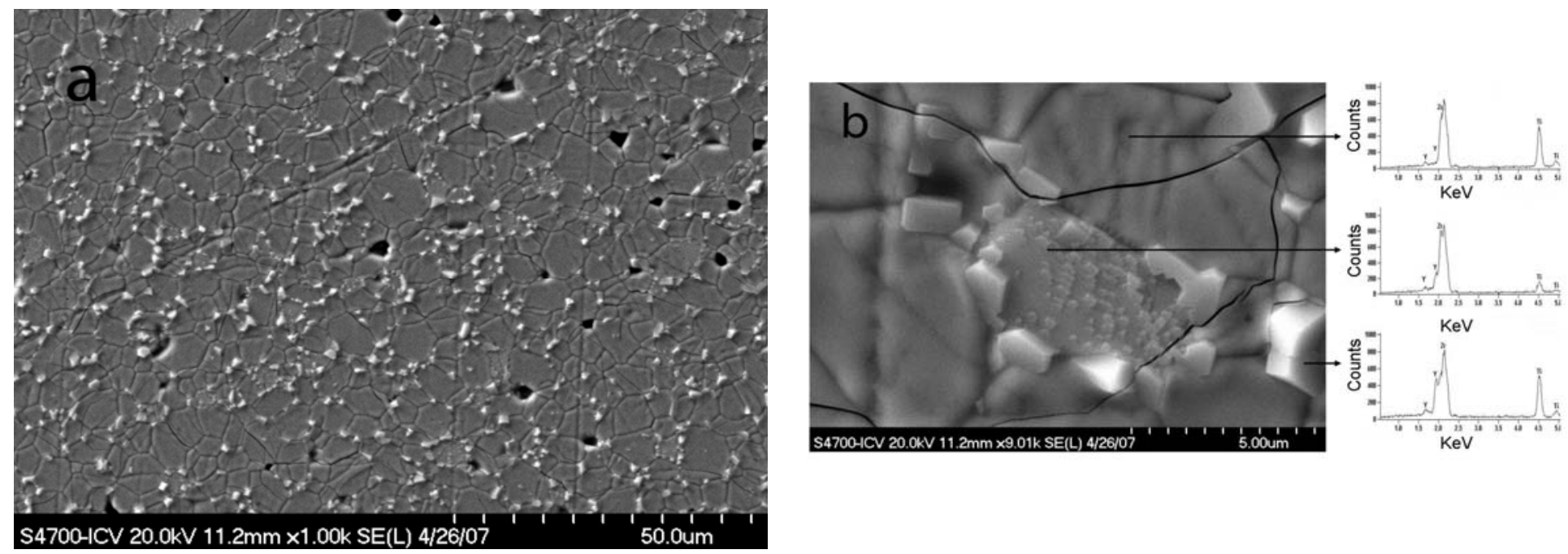

Figure 11. Microstructure of the composites ZT50 sintered at $1500^{\circ} \mathrm{C} / 2 \mathrm{~h}$. FE-SEM micrographs of polished and thermally etched $\left(1400^{\circ} \mathrm{C} / 1 \mathrm{~min}\right)$ surfaces, together with characteristic EDX analyses. Semiquantitative analyses gave a major phase $\left(\approx 53-57\right.$ wt.\% $\mathrm{ZrO}_{2}, 41-43$ wt.\% $\mathrm{TiO}_{2}, 2-3 \%$ wt.\% $\left.\mathrm{Y}_{2} \mathrm{O}_{3}\right)$ that could be identified as $\mathrm{Zr}_{5} \mathrm{Ti}_{7} \mathrm{O}_{24}$, meanwhile the second phase $\left(\approx 62-64\right.$ wt.\% $\mathrm{ZrO}_{2}, 14-18$ wt.\% $\mathrm{TiO}_{2}$, 19-23\% wt.\% $\mathrm{Y}_{2} \mathrm{O}_{3}$ ) should correspond to $\mathrm{c}-\mathrm{ZrO}_{2}$ with a certain amount of $\mathrm{TiO}_{2}$ and $\mathrm{Y}_{2} \mathrm{O}_{3}$ in solid solution, and the minor third phase $\left(\approx 40-45\right.$ wt. $\% \mathrm{ZrO}_{2}, 27-33$ wt. $\% \mathrm{TiO}_{2}, 24-30$ wt. $\left.\% \mathrm{Y}_{2} \mathrm{O}_{3}\right)$ should be pyrochlore.
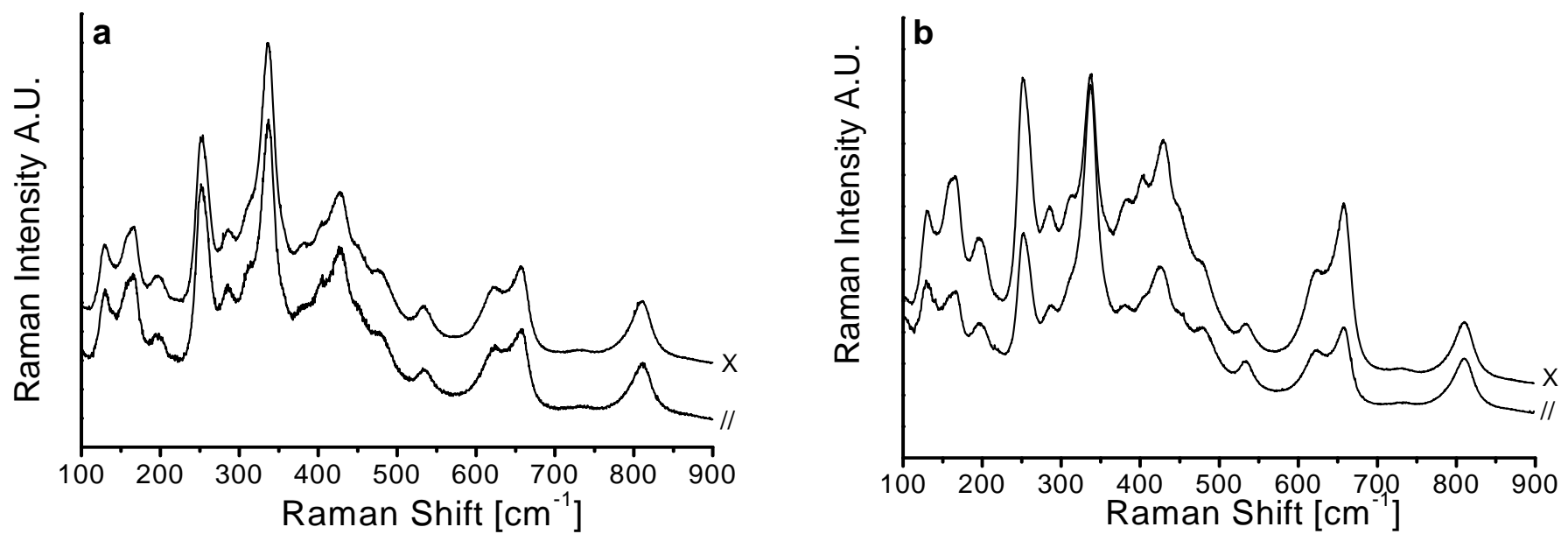

Figure 12. Raman spectra of composites ZT50 sintered at $1500^{\circ} \mathrm{C} / 2 \mathrm{~h}$. (a) Spectra of the major phase $\left(\mathrm{Zr}_{5} \mathrm{Ti}_{7} \mathrm{O}_{24}\right)$; (b) Spectra of the microcrystals of the minor third phase. (x crossed configuration, // parallel configuration). 


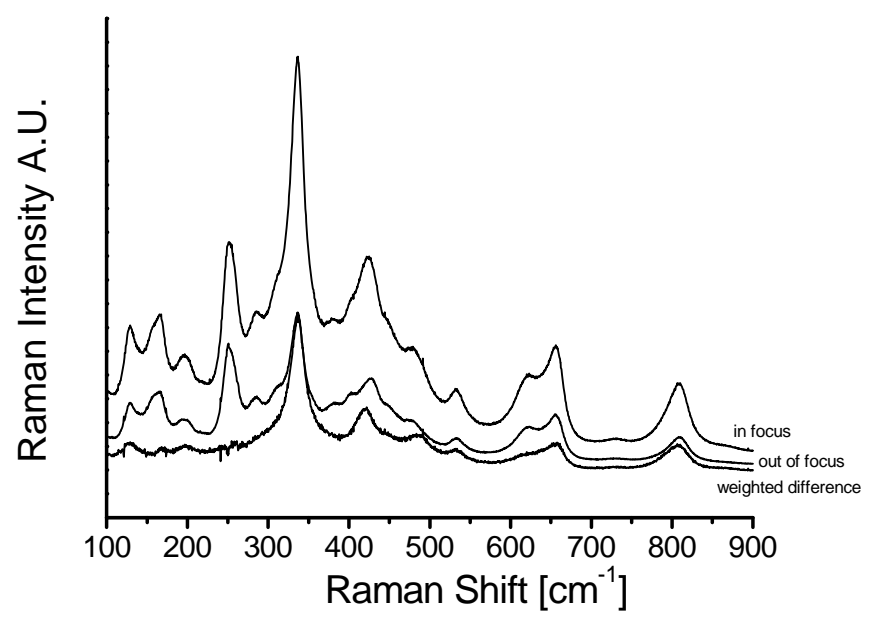

Figure 13. Raman spectra in focus, out of focus and weighted difference, of the microcrystals of the minor third phase in composites ZT50 sintered at $1500^{\circ} \mathrm{C} / 2 \mathrm{~h}$.

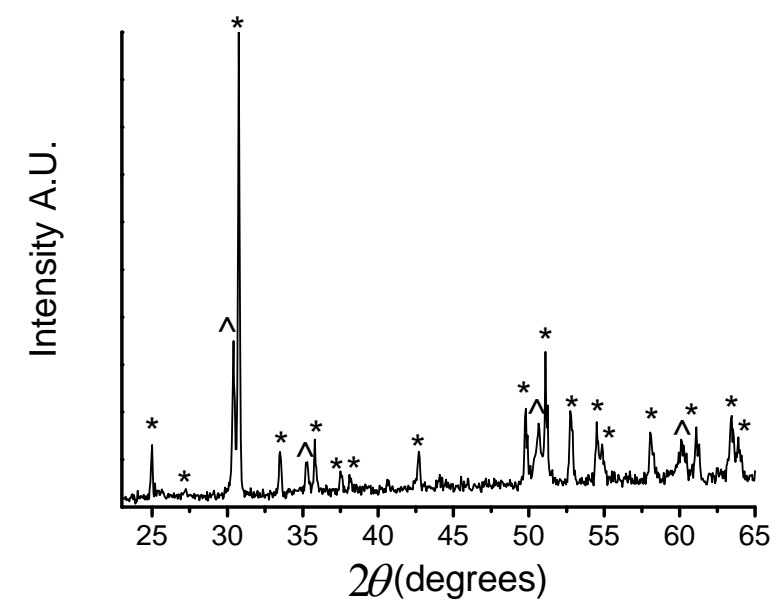

Figure 14. X-Ray diffraction pattern of the composites ZT50 sintered at $1500^{\circ} \mathrm{C} / 30 \mathrm{~h} .{ }^{*} \mathrm{Zr}_{5} \mathrm{Ti}_{7} \mathrm{O}_{24}, \wedge_{\mathrm{c}-\mathrm{ZrO}_{2} \mathrm{Ss}}$ 

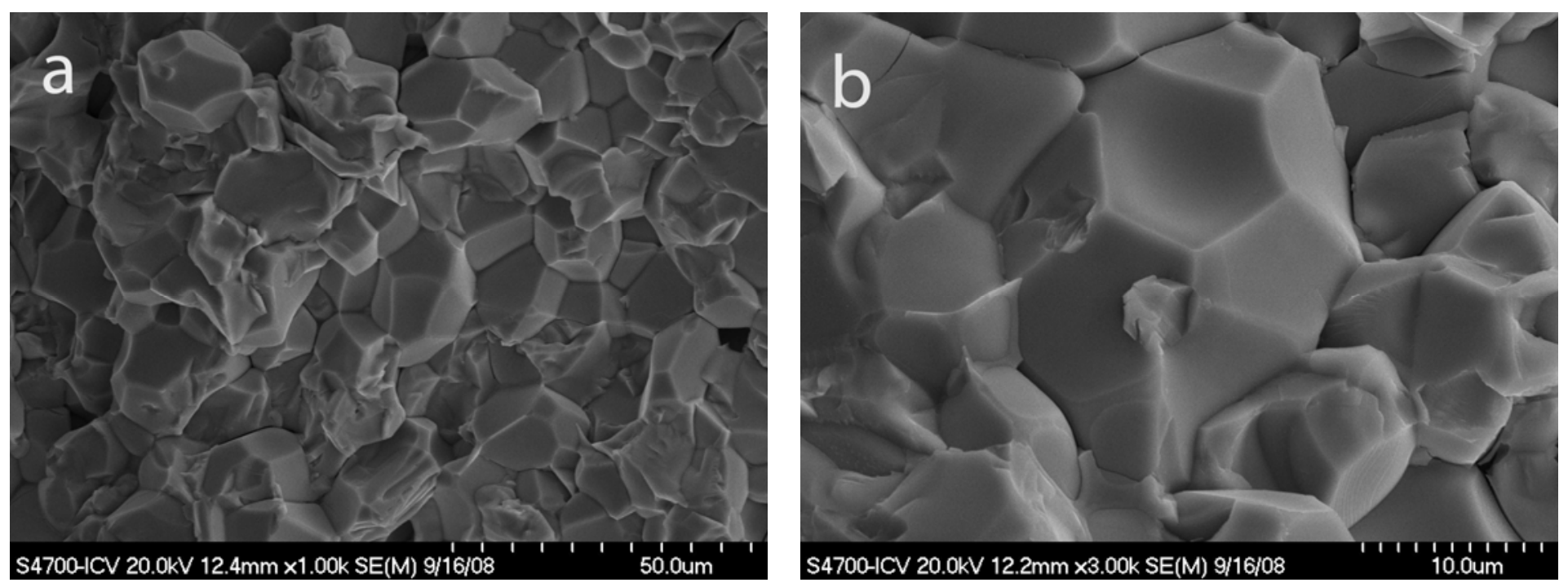

Figure 15. Microstructure of the composite ZT50 treated at $1500^{\circ} \mathrm{C} / 30 \mathrm{~h}$. FE-SEM micrographs of fracture surfaces. The phase that presents transgranular fracture was identified as $\mathrm{Zr}_{5} \mathrm{Ti}_{7} \mathrm{O}_{24}$ (Fig. 16). The grains that present intergranular fracture were identified as $\mathrm{c}-\mathrm{ZrO}_{2}$ (Fig. 16).
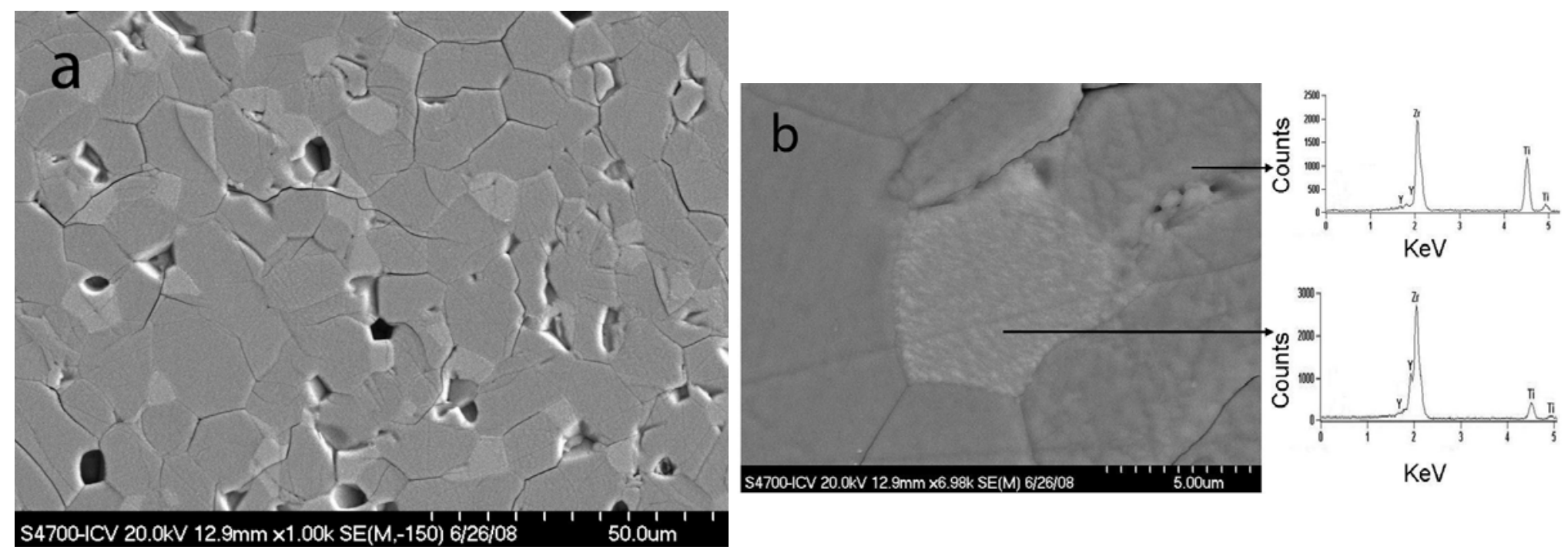

Figure 16. Microstructure of the composites ZT50 sintered at $1500^{\circ} \mathrm{C} / 30 \mathrm{~h}$. FE-SEM micrographs of polished and thermally etched $\left(1400^{\circ} \mathrm{C} / 1 \mathrm{~min}\right)$ surfaces, together with characteristic EDX analyses. Semiquantitative analyses gave a major phase ( $\approx 61-63$ wt. $\% \mathrm{ZrO}_{2}, 33-35$ wt. $\% \mathrm{TiO}_{2}, 1-3 \%$ wt. $\left.\% \mathrm{Y}_{2} \mathrm{O}_{3}\right)$ that could be identified as $\mathrm{Zr}_{5} \mathrm{Ti}_{7} \mathrm{O}_{24}$, meanwhile the second phase $\left(\approx 64-66\right.$ wt.\% $\mathrm{ZrO}_{2}, 10-12$ wt.\% $\mathrm{TiO}_{2}, 23-25$ wt. $\left.\% \mathrm{Y}_{2} \mathrm{O}_{3}\right)$ should correspond to c$\mathrm{ZrO}_{2}$ with a certain amount of $\mathrm{TiO}_{2}$ and $\mathrm{Y}_{2} \mathrm{O}_{3}$ in solid solution. 

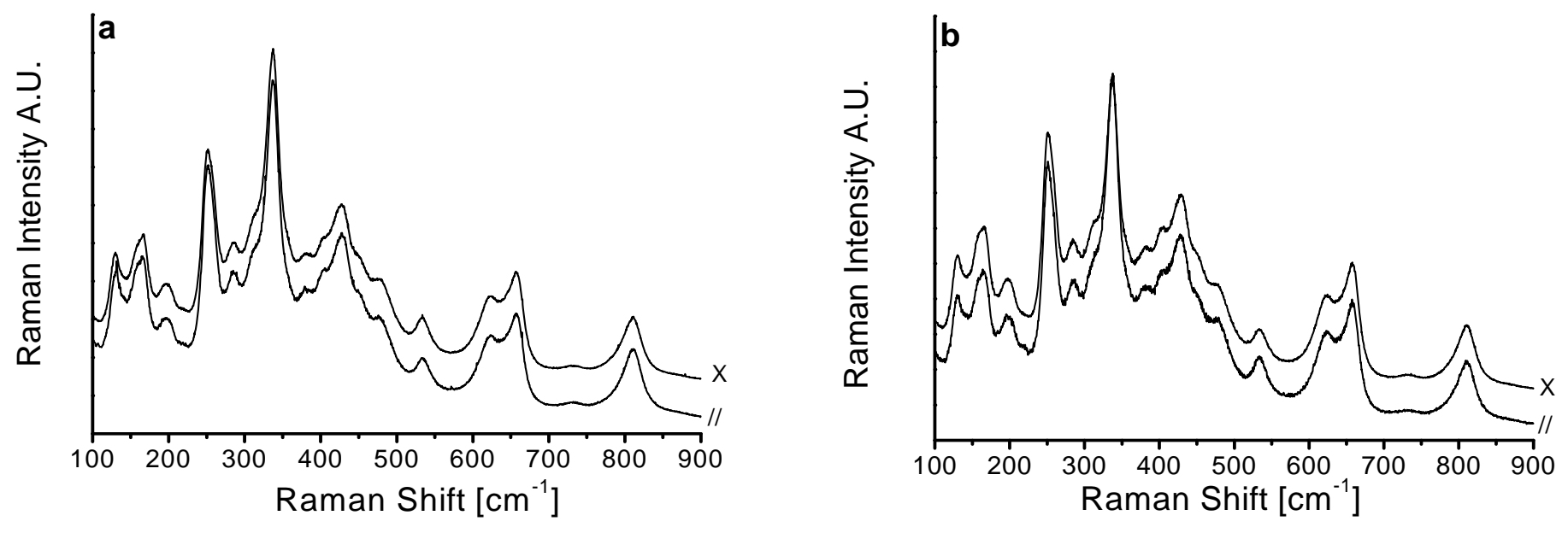

Figure 17. Raman spectra of composites ZT50 sintered at $1500^{\circ} \mathrm{C} / 30 \mathrm{~h}$. (a) Spectra of the major phase $\left(\mathrm{Zr}_{5} \operatorname{Ti}_{7} \mathrm{O}_{24}\right)$; (b) Spectra of the boundary of the second phase ( $\mathrm{x}$ crossed configuration, // parallel configuration). 